\title{
KING MAKERS \\ Local Leaders and Ethnic Politics in Africa
}

\author{
By DOMINIKA KOTER*
}

\section{INTRODUCTION}

$\mathrm{UCH}$ of the literature on electoral politics in Africa has focused
on one mechanism of electoral mobilization: reliance on shared ethnic identity ${ }^{1}$ between politicians and voters. ${ }^{2}$ We expect voters to have a preference for politicians from the same ethnic group and for politicians to search for votes among their coethnics. These patterns manifest themselves in ethnic voting, namely, voting for a coethnic politician, and in the existence of ethnic parties or candidates, that is, those that garner most of their support from their coethnics. ${ }^{3}$ Indeed, we have many well documented cases of ethnic electoral politics in Zambia, Malawi, Ghana, and Kenya, to name just a few. ${ }^{4}$

There are also, however, places without ethnic electoral patterns in otherwise similar environments. Consider the case of Senegal. Like most countries in Africa, it is a very diverse society, in terms not only

* I would like to acknowledge helpful suggestions from Laia Balcells, Keith Darden, Ellen Lust, Dan Posner, Lisa Simeone, Dan Slater, Paul Staniland, Abbey Steele, Susan Stokes, and three anonymous reviewers, as well as the participants of the Comparative Politics Workshop at the University of Chicago and the Program of African Studies at Northwestern University. Generous support for this research was provided by the Fulbright-Hays Doctoral Research Award and the MacMillan Center for International and Area Studies at Yale University.

${ }^{1}$ The term ethnic identity is conventionally used by comparative political scientists as an "umbrella concept" to denote identities based not only on ethnicity per se but also on language, race, religion, caste, and tribe (Horowitz 1985; Varshney 2002; Wilkinson 2004; Posner 2005). Chandra 2006 suggests that the definition of ethnic identity needs to be tightened to capture exclusively descent-based group membership.

${ }^{2}$ Posner 2005; Bates 1974; Ferree 2004.

${ }^{3}$ I follow Horowitz's conception of these two phenomena. He defines ethnic voting as supporting the party identified with the voter's own ethnic group, no matter who the individual candidates happen to be (Horowitz 1985, 320). He defines ethnically based parties as those "parties that derive their support overwhelmingly from an identifiable ethnic group (or a cluster of groups) and serve the interests of that group" (p. 291). I prefer this definition to some of its alternatives, such as Kanchan Chandra's articulation, which requires overt appeals to ethnicity to classify a party as ethnic. Given that formation of parties based on ethnic identities is outlawed in many African countries, this definition is too restrictive. Parties can cater to ethnic constituencies without making "overt" appeals.

${ }^{4}$ See, for example, Dresang 1974, Posner 2003, and Posner 2005 on Zambia; Kaspin 1995 on Malawi; Chazan 1982 on Ghana; and Ndegwa 1997 and Ajulu 2002 on Kenya.

World Politics 65, no. 2 (April 2013), 187-232

Copyright (C) 2013 Trustees of Princeton University

doi: S004388711300004X 
of ethnicity but also of religion. Its parties do not present substantially different programs, policy debates are rare or nonexistent, and clientelism, or the proffering of material goods in return for electoral support, ${ }^{5}$ is and always has been an important component of political competition. ${ }^{6}$ Yet none of the major parties or candidates has an ethnic or religious base. Instead, each party's electorate is as diverse as the electorate as a whole. Senegal is an illustrative example, but it is not an isolated phenomenon; there are other African countries where we see clientelist, nonprogrammatic competition but no ethnic politics. An index developed by Dowd and Driessen, which measures the association between ethnic identity and vote choice, provides a good illustration of this variation (see Figure 1). The values of the index can be interpreted as the percentage of vote choice that can be predicted by voters' ethnic identity. The graph shows that while ethnicity is a good predictor of vote in some places, such as Benin, Zambia, or Kenya, where it can account for over a third of vote choice, it has little explanatory value in Botswana, Senegal, or Mali (under 20 percent). Why then do ethnic electoral blocs emerge in some countries but not in others?

This question is worth pondering because ethnic voting blocs have negative externalities. Political competition along ethnic lines encourages parties to abandon national platforms and cater to specific groups. ${ }^{7}$ It also creates a zero-sum game: an ethnic group as a whole is either in power or not. Ethnic groups who lose might be marginalized and left without resources. Some studies also suggest that when ethnic voting blocs exist, politicians have fewer reasons to be accountable and voters will tolerate more abuse from politicians. ${ }^{8}$ Finally, close electoral contests between ethnic parties raise the specter of possible violence. This scenario materialized with deadly consequences during the 2007 presidential election in Kenya and in 2010-11 in Côte d'Ivoire. This is not to say that ethnic politics are inherently violent, but that they provide a ready-made script, should postelectoral violence occur.

I argue that direct ethnic mobilization is not as unavoidable as commonly thought. On the contrary, politicians actually select different clientelist strategies in response to the social structure in which political activity takes place. In turn, these choices create variation in electoral patterns. First, I suggest that politicians pursue two distinct modes of nonprogrammatic electoral mobilization: (1) by directly relying on the

\footnotetext{
${ }^{5}$ Definition of clientelism from Stokes 2007.

${ }^{6}$ E.g., Beck 2008.

${ }^{7}$ Wantchekon 2003.

${ }^{8}$ Padró i Miquel 2007.
} 


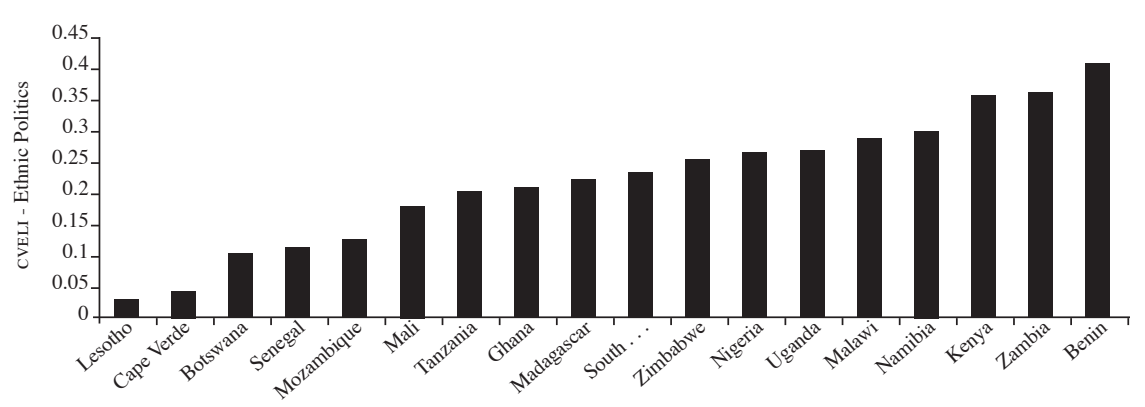

Figure 1

Level of Ethnic Politics (CVELI) in Africa

SouRce: Adapted from Down and Driesen 2008. CveLI measures the association between ethnic identity and vote choice on a scale of 0 to 1.

support of voters from one's own ethnic background and (2) by indirectly working through electoral intermediaries-local leaders who command moral authority, control resources, and can influence the electoral behavior of their dependents. Second, because the power of local leaders varies greatly, the option to use electoral intermediaries is not available in all settings. Finally, the choice of electoral mobilization is neither trivial nor cosmetic: it affects national electoral outcomes. By severing the direct link between politicians and voters, intermediaries reduce a campaign's reliance on shared identity. Rather than being just another link in electoral mobilization, chiefs, religious leaders, or ethnic elites open up the possibility for cross-ethnic electoral patterns. When politicians rely on ethnic solidarity with voters, they tend to create ethnic blocs. Yet politicians who enlist the help of local leaders may be able to access a far broader base of support.

A focus on the social structure in which electoral competition takes place departs from current scholarship on ethnic politics, which tends to emphasize the effect of electoral math and demographics. ${ }^{9}$ Although this group-size logic provides a valuable tool, I argue that it neglects important mitigating factors influencing the dynamics of a political campaign. Politicians do not look only at census numbers; they also pay attention to patterns of influence and dependence. Rather than trying to impose an optimal mobilization strategy based on demographic data, politicians respond to preexisting networks and channels of authority.

${ }^{9}$ Chandra 2004; Posner 2005. 
The evidence for my argument is the result of fieldwork in Senegal and Benin during the 2006-7 electoral season, coupled with a historical analysis of the first mass elections in these countries in the 1950s. These cases are particularly instructive: they are highly diverse societies, with multiple ethnic identities and widespread clientelist politics, that have nonetheless displayed very different electoral patterns (see Figure 1). The empirical analysis starts with a careful examination of the variation in social structure on the eve of mass politics, by looking at the historical legacy of precolonial and colonial politics. The analysis of local elites' standing prior to the first mass elections is essential to isolate the sequence, the process, and the effect of social structure on electoral mobilization. ${ }^{10} \mathrm{I}$ then account for how the position of local leaders has been reproduced since independence, which explains why similar electoral patterns persist to this day. I further use original interviews with political leaders ${ }^{11}$ and media coverage of elections, in addition to secondary sources, to show for both the subnational level and the cross-national level that wherever politicians encountered powerful local elites, they used them as electoral intermediaries to mobilize voters, instead of appealing directly to ethnic groups. In the absence of strong local leaders in Benin, politicians pursued ethnic politics, as we would expect, both during the first wave of mass electoral politics in the 1950 s and during contemporary electoral contests. ${ }^{12}$ In Senegal, however, politicians came to rely over time on powerful local elites in different parts of the country, creating cross-ethnic allegiances and avoiding ethnic voting blocs.

\footnotetext{
${ }^{10}$ See Mahoney and Rueschemeyer 2003, 6, who highlight that one of the main benefits of the comparative-historical approach is that it offers systematic and contextualized comparison, concern with causal analysis, and emphasis on process.

${ }^{11}$ Between September 2006 and May 2007, I interviewed over fifty political actors, mainly MPs, but also campaign managers and experts. I relied on a snowball technique with multiple entry points to assure a broad selection of politicians from both the opposition and the incumbent camps, while also representing the main political formations in each country. Since none of my interviewees asked to remain anonymous, I provide their actual names and positions throughout the text. I combine these firsthand accounts from politicians and intermediaries with an extensive study of political campaigns in both countries. To gather further contextual information, I attended multiple political rallies and campaign events.

${ }_{12}$ This article is primarily concerned with presidential candidates and parties, rather than with individual candidates in legislative elections, given the high centralization of power, especially in former French colonies. Francophone West African countries have a closed-list voting system in multimember districts: voters do not vote for particular MP candidates but vote instead for parties and presidential candidates. In addition, control over party lists is highly centralized: it is the party that determines who will be placed on the party list (dropping sitting MPs from the list is not uncommon) and in which order.
} 


\section{Politicians and Voters in Clientelist Settings}

\section{The Ethnic Mechanism}

Reliance on shared ethnic identity to forge electoral linkages between politicians and voters has been theorized in depth. ${ }^{13}$ Previous studies suggest that in situations of information scarcity, such as when credible policy platforms are lacking, voters use ethnic cues to evaluate candidates in elections. Most scholars, following in Bates's tradition, further argue that voters choose coethnic candidates because they expect material gains, rather than for any symbolic or affective reasons. ${ }^{14}$ For example, Chandra and Posner both claim that ethnic affiliation communicates credible information about which groups will benefit if a given party or candidate wins an election. ${ }^{15}$ As van de Walle puts it, "[C]itizens may feel that only a member of their own ethnic group may end up defending the interests of the ethnic group as a whole, and that voting for another ethnic group will certainly not do so."16 Shared ethnicity is supposed to ensure that politicians do not renege on their electoral promises because, while a single constituent would have no way of enforcing such commitments, the group as a whole has the power to withdraw future support. Knowing that ethnicity acts as an information shortcut for voters, politicians tend to look for electoral support among their coethnics. Note that this type of electoral mobilization rests on a rather passive mechanism. If shared ethnicity coordinates voters' behavior, all politicians have to do is showcase their ethnic identity to voters. In many cases, presenting oneself as a champion of a certain ethnic group does not require much effort: one's name, dress, or area of origin may already contain all the necessary information. If voting behavior depends on a link of identification with the politician, this link need not be personal.

This strategy has some obvious benefits for politicians, mainly, that it is easy to signal. Yet it also has important limitations. Nominal ethnic ties may be less amenable to clientelism than is commonly thought. Ethnic ties are supposed to matter because they can serve as channels of clientelism; at the same time they do not inherently possess many of the features that are typically viewed as necessary for clientelism, such as personal relationships. Both classic and more contemporary studies of clientelism place a great deal of emphasis on personal ties as the basis

\footnotetext{
${ }^{13}$ Inter alia Horowitz 1985; Posner 2005; and Chandra 2004.

${ }^{14}$ Bates 1974.

${ }^{15}$ Chandra 2004; Posner 2005.

${ }^{16}$ van de Walle 2007, 65.
} 
for distributing resources. ${ }^{17}$ They highlight "personalized reciprocal relations between an inferior and a superior" and "personal problemsolving networks." ${ }^{18}$ Ethnicity alone does not guarantee such relations between individuals.

For voters, nominal ethnic ties with a national politician might not guarantee access to resources. There is in fact empirical evidence that brings into question the material benefits enjoyed by coethnics of officeholders. For example, Kasara shows that in Kenya peasants from the president's ethnic group are actually taxed at a higher rate than other ethnic groups. ${ }^{19}$ Wrong argues that ordinary Kikuyus have "little to show for being from the president's tribe." ${ }^{20}$ Similarly, van de Walle finds no ethnic favoritism in Uganda. ${ }^{21}$ More recent studies find some evidence of ethnic favoritism, but they also highlight that such effects are variable across countries and that the conclusion one reaches depends on the specific goods analyzed. ${ }^{22}$ Ethnic support is often based more on perceptions than on concrete patterns of redistribution ${ }^{23}$ and may rest on the hope of gaining access to resources rather than on actual benefits delivered. Thus, in political environments with alternative problem-solving networks, appeals to ethnicity may not be the best strategy.

\section{MobiLiZing THROUGH INTERMEDIARIES}

In their quest to win votes, politicians may employ traditional chiefs, religious dignitaries, or other local leaders as electoral intermediaries. In doing so, they take advantage of preexisting relations of dependence. The strength of local leaders rests on their degree of authority and provision of material assistance. In the context of weak states, local leaders who enjoy the trust of their community play a very important role in peoples' lives. In many developing countries, the scarcity of public goods and the difficulties in obtaining basic services from the state are striking. As Krishna has shown in the context of India, most poor people cannot interact with the state on their own, and they are unable to secure the necessary services independently. ${ }^{24}$ At the same time, politi-

\footnotetext{
${ }^{17}$ For examples of classic studies of clientelism, see Scott 1972; and Lemarchand and Legg 1972. More contemporary examples include Stokes 2007; and Brusco, Nazareno, and Stokes 2007.

${ }^{18}$ Lemarchand and Legg 1972; and Brusco, Nazareno, and Stokes 2007, respectively.

${ }^{19}$ Kasara 2007.

${ }^{20}$ Wrong 2009, 52-53.

${ }^{21}$ van de Walle 2007, 65.

${ }^{22}$ Franck and Rainer 2012; Kramon and Posner 2011; Kramon and Posner 2012.

${ }^{23}$ See also Posner 2005, chap. 4.

${ }^{24}$ Krishna 2011.
} 
cal parties or local governments are not the most popular channels for gaining access to desired goods. ${ }^{25}$ Such an environment creates demand for intervention by local leaders. These individuals often act as social mediators, control access to resources, and provide valuable goods and services. In sum, they provide essential safety nets to their dependents in an environment of poverty and unmet needs. Admittedly, the relationship between local leaders and their followers is complex, in that it can be based both on reciprocity and on some degree of exploitation. Voters can trust and rely on their leaders but also feel trapped in their subordinate position.

Intermediaries allow national politicians to access an electorate where the latter otherwise have no reservoir of trust, as is the case among non-coethnics. Local leaders can affect the voting preferences of their dependents and assist them in accessing resources. By "bundling" votes, intermediaries gain leverage to acquire promises of resources on behalf of their followers. For voters, the logic of following an intermediary's suggestion is simple. Voters want to find a champion who can provide assistance to them and their community. But that champion need not be a politician from their ethnic group. Knowing a patron with government connections may be more advantageous than relying on the campaign promises of redistribution to their ethnic group by someone they cannot easily reach. When voters depend more on local leaders than national politicians for most of their needs, they are more likely to be swayed by the former when casting their ballot. If a voter's benefactor profits from the election of a particular candidate or party, such a voter can expect to experience diffuse benefits. In following an intermediary, voters are thus simultaneously repaying him for past and ongoing benefits and trying to secure future advantages.

When electoral politics is clientelist in nature, as is the case in much of Africa, reliance on intermediaries presents an appealing mobilization strategy for politicians. Instead of reaching out to the public on the basis of impersonal ties, politicians can create constituencies through personal connections between voters and their leaders. In doing so, they are taking advantage of the actual networks that people use in their daily lives. Personal relationships between local leaders and voters are valuable to politicians because of the difficulty of monitoring voters' behavior. As van de Walle points out, African parties have little capacity to enforce vote counting. ${ }^{26}$ Vicente and Wantchekon highlight

\footnotetext{
${ }^{25}$ Krishna 2011,109.

${ }^{26}$ van de Walle 2007, 53, 64.
} 
that in the context of a secret ballot, there is no clear enforcement mechanism for individual vote buying. ${ }^{27}$ Politicians could distribute gifts or cash before the election, but they have no effective strategy for ensuring that voters will indeed support them. ${ }^{28}$ Engaging in direct vote buying on a mass scale is thus not a viable option for politicians or parties. African parties further lack their own agents to assist with voter mobilization, as might be the case with more institutionalized parties, for example, in Latin America.

Instead, candidates or parties can subcontract mobilization to established local leaders with strong ties to the population. Ties of dependence between local authority figures and their followers, what I call bierarchical ties, ${ }^{29}$ are particularly suitable for the creation of clientelist networks and voter mobilization because they provide the necessary "social cement," to borrow Susan Stokes's term. ${ }^{30}$ Clientelist systems thrive on deeply rooted organizational structures, based on face-to-face interactions, personal loyalty, and the social embeddedness of local power brokers. ${ }^{31}$ Most importantly, while it is very difficult, if not impossible, to monitor individual voters, it is easy to observe the electoral behavior of blocs of voters controlled by local intermediaries. In many countries, electoral results are available for every voting bureau, with only several hundred voters in each one, allowing politicians to reward or punish a whole unit. For example, in Senegal, electoral results are publicly displayed for each polling station; the stations range in size from four hundred to eight hundred registered voters, typically one per village. ${ }^{32}$

\section{Choosing Electoral Strategies in Response to SOCIAL STRUCTURE}

While the option of using intermediaries may be appealing to politicians, the viability of the approach depends on the strength of local leaders. The robustness of ties binding local leaders to their dependents is crucial. In the absence of effective mechanisms for monitoring

\footnotetext{
${ }^{27}$ Vicente and Wantchekon 2009, 294.

${ }^{28}$ Banégas 2003, 430, discusses this issue in the context of Benin, highlighting that many voters take money from multiple parties but vote according to other criteria, mostly ethnic identity. Incidentally, many anti-vote-buying campaigners do not discourage people from accepting gifts from politicians; rather, they tell them to take what is offered but to vote their conscience. This approach illustrates politicians' inability to effectively monitor individual voters.

${ }^{29}$ I use the term "hierarchical tie" to denote the asymmetry of authority between a leader and a dependent. Hierarchy reflects the relationship between people of superior and inferior status. For lexical variety, I use "hierarchical ties" and "ties of dependence" interchangeably throughout the article.

${ }^{30}$ Stokes 2007.

${ }^{31}$ Stokes 2007; Schaffer and Schedler 2007; Powell 1970.

${ }^{32}$ Personal communication with Babacar Kante, vice president of the Constitutional Council (Conseil Constitutionnel), a body overseeing elections, Dakar, Senegal, February 2, 2007.
} 
individual voters, intermediaries have to rely on their social clout to induce compliance. Put simply, leaders need strong ties to their dependents if they are to influence their vote. Voters are likely to follow intermediaries when they depend on them financially and trust them to make decisions on behalf of the community. In order to have electoral sway, local leaders need to affect the well-being of those around them and enjoy a substantial amount of deference. In sum, the strength of the ties determines voters' compliance. Moreover, robust hierarchical ties are also essential for intermediaries to be able to strike deals with politicians. A demonstrated position of authority in a community is necessary to convince politicians that one is capable of delivering votes, even across ethnic and confessional lines. This is precisely why the function of intermediary can be performed only by local leaders with strong hierarchical ties to the population.

Yet not all communities have meaningful hierarchical ties and not all chiefs or religious leaders are suited to become electoral intermediaries. ${ }^{33}$ Even though religious and customary authorities exist across Africa, their prominence varies greatly. Boone notes that there have been marked historical differences in communal structures across Africa. ${ }^{34}$ For example, while the Northern Senoufo of Côte d'Ivoire have tangible authority figures, the "rural social structures across the South [of Côte d'Ivoire] shared a common social-structural feature: the extreme weakness of indigenous political hierarchy." ${ }^{35}$ Nowadays, the standing of local leaders is not uniform either. Logan points out that while over three-quarters of Malians trust their traditional leaders, fewer than than one-third of Nigerians do so. ${ }^{36}$ This varying strength of local elites is consequential. As much as it might be tempting for political parties to manufacture intermediaries where they have hitherto been lacking, such efforts are likely to fail. Strong relationships between local leaders and their followers are not built overnight. In any given election, therefore, politicians must work with a preexisting set of leaders, rather than trying to create them de novo. ${ }^{37}$

${ }^{33}$ As one senior Senegalese politician pointed out, many people are posturing to be potential intermediaries. As he noted, politicians are skeptical that such "upstarts" have any influence over voting behavior, when compared with more established power brokers, such as the marabouts; author interview with Mbaye-Jacques Diop, Dakar, March 1, 2007.

${ }^{34}$ Boone 2003, 29.

${ }^{35}$ Boone 2003, 181.

${ }^{36}$ Logan 2008.

${ }^{37}$ This does not preclude change in the intermediary landscape in the long term. Politicians' actions might influence the standing of local leaders over a period of time. I do suggest, however, that while one could swiftly undermine local leaders, it is much harder to create authority in a short period of time. 
While there are clear benefits to relying on intermediaries, one might question whether politicians will actually use them. Perhaps they could forgo the benefits of using intermediaries and try instead to appeal directly to voters. Where local leaders are strong, however, bypassing them carries potential costs. If local leaders are able to mobilize support in someone's favor, they are just as capable of demobilizing voters for a given politician, either by discouraging turnout or by encouraging voters to support someone else. When facing the choice of using intermediaries, politicians must thus weigh both the "carrots" and the "sticks" that present themselves. Given the combined effect of the benefits of using local leaders and the costs of bypassing them, politicians are very likely to employ them as electoral intermediaries.

One additional caveat is in order: while the mobilization of ethnic groups and the mobilization of intermediaries are not mutually exclusive acts, they are not always complementary. In principle, politicians could rely on both strategies simultaneously. However, once intermediaries enter the electoral arena, it is likely that they will deal with the highest bidder from across the ethnic spectrum, undermining politicians' efforts to invoke ethnic solidarity.

\section{EFfect on Electoral Patterns}

Not surprisingly, the direct mobilization of shared ethnicity results in ethnic voting blocs. In contrast, when politicians use intermediaries, both actors have incentives to work across ethnic lines. For intermediaries, the advantages of engaging in political mobilization are straightforward: they can convert their social clout into material gains by cashing in on their involvement in the community. Support for a successful candidate may translate into wells, roads, or other public goods for their locality. In addition, intermediaries may also expect personal goods, including cash, political positions, or gifts in kind. For politicians, intermediaries are valuable because of their ability to deliver votes, a service that is particularly important when parties are weak, as is the case in most of Africa and much of the developing world. Politicians are willing to negotiate deals with intermediaries that involve exchanging resources for blocs of votes.

In the context of weak and nonprogrammatic parties, transactions between politicians and intermediaries resemble a free market, where neither set of actors would have any incentive to limit itself to working with members of the same group. ${ }^{38}$ Politicians want to find the most

\footnotetext{
${ }^{38}$ In settings in which ideology is more salient, there will inevitably be greater constraints on brokers. In Argentina, for example, a Peronist broker would not be able to switch to the Radical Party and convince his dependents to follow him.
} 
efficient intermediaries, whereas intermediaries favor those politicians best positioned to provide resources. Narrowing the range of acceptable patrons only to coethnics would limit intermediaries' prospects of material rewards. Rather, it is in the intermediaries' interest to keep their options open to land the most lucrative offer possible. I argue that the intermediaries' choice of political patron depends largely on material benefits. In brief, they have a preference for the politician who can offer them the best deal. ${ }^{39} \mathrm{I}$ therefore expect that when intermediaries can get higher rewards for themselves and their community from noncoethnics, they will support those candidates over coethnics.

It is a rare scenario when all politicians have comparable resources at their disposal and can make equally appealing offers to intermediaries. On average, incumbent presidents and their parties ${ }^{40}$ have an advantage over challengers. There are two types of rewards that politicians can offer: direct payments or gifts in kind during electoral campaigns and promises of future rewards contingent on electoral results. Actors mix pre- and postelectoral payoffs because the two types of rewards have important but different functions. On the one hand, rewards given before the election are disadvantageous to politicians because there is no clear enforcement mechanism. ${ }^{41}$ An intermediary could take the reward and not even try to deliver. On the other hand, while politicians might prefer to distribute benefits after the election to ensure enforcement and to reward actual intermediary support, promises of postelectoral transfers might not seem credible to intermediaries. This presents a particular hurdle for challengers, who do not have an established track record and whose likelihood of winning may be perceived as relatively low, given the traditionally high reelection rates in Africa. ${ }^{42}$ Given the uncertainty of postelectoral payoffs, intermediaries expect, or hope, to receive some rewards before the polls..$^{43}$ Because

\footnotetext{
${ }^{39}$ One side effect of intermediaries' preference for the highest bidder is a possible "bandwagon effect," namely, a majority of vote carriers flock to the best-endowed candidate when one candidate or party has a substantial material advantage over others. On the bandwagon effect, see Scott 1972, 110.

${ }^{40}$ When talking about incumbency advantage, especially in the context of French West Africa, it makes most sense to talk about the incumbent president and his party rather than incumbent MPs. As van de Walle 2003 points out, most African systems exhibit excessive presidentialism: most power and control of the state coffers rest with the president and his entourage. Individual incumbent MPs have little power, as explained in fn. 12 .

${ }^{41}$ On this point, see, for example, Vicente and Wantchekon 2009, 294.

${ }^{42}$ See, for example, Vicente and Wantchekon 2009, who argue that promises of postelectoral rewards on the part of the incumbent seem more credible (pp. 293-95, 300-301). Furthermore, Magaloni 2006 (e.g., 19) argues that an established track record and uncertainty about the opposition's likely behavior in office are important components of the incumbency advantage.

${ }^{43}$ In this respect, gifts distributed prior to electoral contests serve an important function: by channeling resources, a given politician presents himself as a viable, serious, and generous candidate. Such payoffs might be necessary to establish oneself as a contender and to signal the strength of one's campaign.
} 
of the trade-offs between the two types of rewards for the two sides, actors try to combine both pre- and postelectoral payoffs. In general, these conditions on average favor the incumbent and his party. They are the ones who can give more credible promises about postelectoral redistribution, as highlighted above, and they can draw on their access to state coffers to give out resources before the election. ${ }^{44}$ However, the incumbents' perpetual reelection is not inevitable: presidential term limits or acute economic crises, which reduce resources available to incumbents, can create openings for the opposition.

Intermediaries have not only the incentives but also the means to forge ties with non-coethnic politicians. While an individual voter might trust only a coethnic to deliver, intermediaries are in a structurally better position to drive a hard bargain with any politician. Intermediaries with a substantial base have bargaining chips: they can credibly threaten to work against a given political actor, either by defecting to a different candidate or party or by discouraging turnout. Once in office, incumbents are also ill advised to renege on promises made to intermediaries, because the latter can support someone else in future elections. Intermediaries who have a track record of delivering votes to politicians can exact a high price because they seem reliable. They can point to past results to prove their mobilization prowess. ${ }^{45} \mathrm{It}$ is the reputation of effective vote getters that enables intermediaries to cut lucrative deals with politicians. Since intermediaries have both the incentives and the means to work across the spectrum of ethnic identity,

${ }^{44}$ State coffers might not always be vast but they are not negligible. Even in countries lacking mineral wealth or oil, such as Senegal, incumbents can draw on considerable state resources, and thus they tend to have a financial advantage over the opposition. For example, in her study of the 1996 local elections in Senegal, Patterson 2002 found that the ruling PS was able to distribute much more funds on the eve of the election than the opposition PDS. Several opposition leaders whom I interviewed during the 2007 presidential election in Senegal, including presidential candidate Ousmane Tanor Dieng, decried the vast size of President Wade's war chest. This is consistent with Vicente and Wantchekon 2009, who also state that incumbents have a "pre-election disproportionate control of public resources and allocations" (p. 294). Admittedly, if all resources were given out prior to elections, perhaps incumbents' dominance would not be as substantial, depending on the war chest of their opponents. Challengers' personal wealth or other sources of campaign funds (for example, from the diaspora) could mitigate some of the incumbency advantage. Yet even wealthy challengers are hampered to some extent by the difficulty of making credible promises of postelectoral rewards, as explained above. These conditions thus on average create a proincumbency bias. Importantly, the issue of incumbency advantage should not affect our predictions about the relationship between the use of intermediaries and less pronounced ethnic politics. As I postulate, intermediaries have a preference for the candidate who can distributes the most resources. In most cases in Africa that is likely to be the incumbent. However, the argument that intermediaries will favor the highest bidder rather than a coethnic, unless the two overlap, holds regardless of whether that candidate is an incumbent or a challenger.

${ }_{45}$ Even in first-time elections intermediaries can usually point to success in other mobilization efforts: for example, some local leaders in French West Africa helped recruit wartime volunteers to serve in the French army. 
this form of mobilization leads to more diverse electoral patterns, to the exclusion of ethnic voting blocs.

\section{Social Structure and Electoral Mobilization IN West AFricA}

Let us now apply this argument to West Africa, by comparing Senegal and Benin at both subnational and cross-national levels. In brief, they are exactly the type of places where we would expect to see "ethniccensus" politics. They are both highly diverse societies, with multiple ethnic identities that politicians could potentially mobilize. These cases also share many historical and institutional commonalities: both were part of the same colonial unit (French West Africa), have similar electoral institutions (presidential systems with closed-list voting in legislative elections), and are considered to be clientelist democracies.

My analysis begins with a comparison of local leadership regionally and between the two countries. As I suggested, only strong local leaders can become effective electoral intermediaries. The historical analysis that follows serves to explain why politicians found potential intermediaries in some places but not in others. Because the standing of local leaders could have been conditioned by involvement in elections, it is essential to look at the state of local social structures prior to the onset of mass politics. This is possible with respect to French West Africa, where mass electoral politics first started in the 1950s. While Africans had been participating in elections to the French National Assembly as early as 1875 in Senegal, those with the right to vote represented only a tiny fraction of the colonies' inhabitants. It was not until 1951 that the French parliament dramatically extended suffrage: in Dahomey, present-day Benin, the number of eligible voters increased sixfold (from 54,208 to 334,435), whereas in Senegal, the same reform more than tripled the electorate from 200,000 to 655,000. ${ }^{46}$ A few years later, in 1956, the French parliament passed Loi cadre (dubbed in English "The Enabling Act"), which introduced universal suffrage for African voters. ${ }^{47}$ As a result of these reforms, African electoral contests changed within just a few years' time from a privilege of the urban elite to a popular contest for office.

I will then show how modes of electoral mobilization have mirrored different social structures, both historically and at present: where there

\footnotetext{
${ }^{46}$ Respectively, Thompson 1963,174-75; and Cruise O’Brien 1971, 266.

${ }^{47}$ Thompson 1963, 178.
} 
were local leaders with strong hierarchical ties to the population, politicians used them as intermediaries, whereas where they were absent, politicians relied directly on their ties with voters. Finally, we will see how these different types of mobilization result in distinct electoral outcomes, with or without ethnic electoral patterns.

\section{Historical Legacy: DifFerent Landscapes \\ of Social Structure}

On the eve of mass politics local leaders in different regions of Senegal and Benin had remarkably variegated levels of power. This inconsistency is a historical legacy - an outcome of both precolonial power structures and the transformative impact of colonial rule. Some areas never had powerful local elites, other places once had important elites whose power eroded under colonial rule, and in some regions local hierarchies persisted. In the following paragraphs I describe and account for the differential strength of local leaders in our cases.

\section{SENEGAL}

Historically, there were two types of powerful elites throughout most of Senegal: religious clerics from Sufi brotherhoods, known as marabouts, and traditional, caste-based elites. ${ }^{48}$ Both elites long predate the colonial invasion, let alone the onset of mass politics. Sufi Islam arrived in West Africa in the late eighteenth century, spreading out from North Africa and the Middle East. ${ }^{49}$ Caste structures, which are the underpinning of the traditional elites' status, emerged sometime between 1300 and $1500 . .^{50}$ Yet not all elites survived the imposition of colonial rule. Remarkably, though, throughout most of the country, wherever one set of elites perished, the other set retained control. The only exceptions in Senegal are the Diola and Balant groups (approximately 5 percent of the population), who populate the Casamance region and who have never had prominent traditional or religious leaders. ${ }^{51}$

In the Senegalese heartland, the once powerful traditional Wolof elites were severely weakened by the French colonizers. Subjected to a relentless military campaign, Wolof leaders who resisted colonial annexation were defeated by the French in $1886 .{ }^{52}$ The French then set out to reorganize the traditional order to their liking and the remaining

\footnotetext{
${ }^{48}$ See Pélissier 1966, 107, 197; Diop 1981; Diouf 1994, 47; and Beck 2008.

${ }^{49}$ Cruise O’Brien 1971, 25.

${ }^{50}$ Tamari 1991, 249.

${ }^{51}$ Beck 2008, 161; Pélissier 1966, 28, 593, 682.

${ }^{52}$ Cruise O'Brien 1971, 13.
} 
Wolof leaders were "reduced to a subordinate status." 53 The religious authorities from the Sufi brotherhoods directly benefited from the weakening of the traditional Wolof elites. As Villalón argues, the collapse of the Wolof social organization following the colonial conquest gave impetus to widespread conversions as Islam filled the "imperatives of reconstructing social orders." ${ }^{54}$ The French created a void of authority that the religious leaders filled. As Klein observes, "Without intending to do so, the French aided the replacement of the chief by the marabout." ${ }^{55}$ The further expansion of the Sufi brotherhoods, especially the homegrown Mouridiyya, can be attributed largely to the fact that "it provided a means of reconstructing the old social order on a new religious basis. ${ }^{" 56}$ As Cruise O'Brien further notes, the religious authorities "took over the status and many of the functions of the discredited chiefs." ${ }^{7}$ The marabouts of central Senegal, especially the Mourides, built substantial authority among the masses by playing a significant role in the lives of their followers and, by cooperating with the French, avoided their own destruction.

The strength of the marabouts' ties with their followers rests on the important social roles that those leaders play, in both the spiritual and the material realms. A key characteristic of Sufi Islam, as it is practiced in the area, is that an individual must become a member of a Sufi order by taking a pledge of allegiance to a marabout. ${ }^{58} \mathrm{~A}$ disciple thus is connected to the order through his personal religious leader, rather than by virtue of a general membership in the brotherhood. Being a follower of a marabout places an individual inside an important network, which has consequences for his advancement and well-being. Marabouts can facilitate the acquisition of essential goods and services and provide a form of social insurance. ${ }^{59}$ Disciples have a sense that should they be afflicted by misfortune, such as illness or drought, they can turn to their marabout for help. This help often extends to finding employment or even a spouse. ${ }^{60}$ In brief, the marabouts "serve as conduits for redistribution," which allows them to maintain their following. ${ }^{61}$ In many cases in central Senegal, the marabouts also control scarce resources such as land, especially in the so-called Groundnut Basin. In fact, they

\footnotetext{
${ }^{53}$ Cruise O'Brien 1971, 14.

${ }^{54}$ Villalón 1995, 61.

${ }^{55}$ Klein 1968, 202.

${ }^{56}$ Cruise O'Brien 1971, 15.

${ }^{57}$ Cruise O'Brien 1971, 15.

${ }^{58}$ Villalón 1995, 64.

${ }^{59}$ Villalón 1995, 124; Coulon 1981, 115.

${ }^{60}$ Coulon 1981, 112.

${ }^{61}$ Villalón 1995, 187.
} 
pioneered the cultivation of an area on the fringe of the Ferlo Desert, outside the traditional zones of agricultural production. ${ }^{62}$ In a system without property titles, ${ }^{63}$ in which peasants were both formally landless and without a guaranteed right to use land, the religious leaders acted as custodians of land (chefs de terre). Only being linked to a marabout gave one the right to cultivation, a fact that underpinned the entire organization of agricultural production. ${ }^{64}$

The significance of personal ties to a marabout exceeded mere affiliation with a religious order. As Villalón claims, "[E]ffective exploitation of the advantages of clientelism can only come by developing personal ties to the marabouts of that order." ${ }^{65}$ Adherence to an order per se has limited sociopolitical consequences. Instead, it is "the nature and extent of personal relationship with a marabout which has a direct impact on an individual's opportunities, and his or her behavior." 66

Whereas the marabouts became the dominant elite in central Senegal, traditional elites eclipsed religious clerics in the Senegal River Valley in the North. When the French colonizers set out to establish direct control in the 1850s, after years of commercial presence, the main resistance encountered was from Tijani marabouts rather than the traditional Tukulor elite, known as the toorobe. ${ }^{67}$ While the French fought and defeated the Tijani marabouts, they embraced the toorobe families who were willing to cooperate with them. As Beck explains: "[under the French rule] the toorobe families who were co-operative allies maintained or even enhanced their power in Tukulor society." 68

As is the case with the marabouts of central Senegal, the toorobe controlled access to land for cultivation or pasture. This aristocratic elite acted as customary landowners regulating agricultural production, by providing access to fertile land in exchange for rents. This "feudal" relationship persisted throughout the colonial period. Thus, at the onset of mass politics the Tukulor peasants were still locked in a relation of dependence with the toorobe nobles. ${ }^{69}$ The authority of the toorobe and their influence over lower Tukulor strata were based on the convention of higher status and reinforced by control of resources. Such

\footnotetext{
${ }^{62}$ Coulon 1989, 112.

${ }^{63}$ The prevailing land tenure system throughout Senegal was based on allocation of land by traditional authorities.

${ }^{64}$ Cross 1968, cited in Coulon 1989, 113.

${ }^{65}$ Villalón 1995, 125.

${ }^{66}$ Villalón 1995, 145.

${ }^{67}$ The singular form of toorobe is toorodo.

${ }^{68}$ Beck 2008, 127.

${ }^{69}$ Beck 2008, 125.
} 
relations of dependence gave the toorobe elite significant influence over their subordinates. Whether through the toorobe or the marabouts, Senegal is largely characterized by strong hierarchical structures.

\section{BENIN}

In comparison to Senegal, at the onset of mass politics Benin had few influential local authority figures. The southern royalty from the two largest precolonial kingdoms, Abomey (Danhomé) and Porto-Novo (Adjacé), was severely undermined by the French colonial conquest and no alternative elites emerged to replace them as the marabouts did in central Senegal. The most important elite, the Fon royalty, fiercely resisted colonial annexation, just like the Wolof rulers. In response, the French replaced them with more compliant individuals of their own choosing. When the territory of Benin was placed under direct rule, the French "revolutionized the organization of the ancient king-

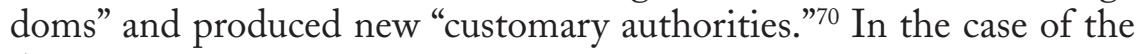
Abomey kingdom, the French deposed King Gbehanzin in 1900, after he refused to surrender to Colonel Dodds. As Glélé notes, the French wanted to "get rid of a king who knew how to use all his ancestral, legitimate rights and who became inconvenient for the French presence." ${ }^{\prime 1}$ In the kingdom of Porto Novo, the French prevented succession after the death of King Toffa, reducing the role of his son and would-be successor, Prince Tolli Toffa, to "superior chief." ${ }^{2}$ As a result, the ancient monarchs were "marginalized [and] reduced to an honorary role." 73

The remaking of hierarchical ties to suit French interests extended beyond kings, to all types of customary chiefs. The colonial power routinely replaced "uncooperative" chiefs and at times even "invented" chiefs where necessary. Yet these newly created hierarchies were seen as illegitimate, and, as Ronen notes, the new chiefs had little power over their subjects. ${ }^{74}$ Similarly, Thompson observes a "widespread rejection of authority in the South." ${ }^{75}$ Already by 1917, the French governor general, Van Vollenhoven, lamented that the direct administration "led to a disaster, by creating the loss of authority of the chiefs traditionally listened to." ${ }^{" 76}$ Glélé further notes that around the time of independence,

\footnotetext{
${ }^{70}$ Banégas 2003, 320.

${ }^{71}$ Glélé 1969.

${ }^{72}$ Glélé 1969, 21.

${ }^{73}$ Banégas 2003, 320.

${ }^{74}$ Ronen 1974, 59-61.

${ }^{75}$ Thompson 1963, 173 .

${ }^{76}$ Quoted in Banégas 2003, 321.
} 
chiefs "were nothing but a relic, the kinglets without treasury, without subjects, having nothing but moral authority and the memories of their former glory." 77

In contrast to the more populous South, which disproportionately affects national politics, patterns of social organization are entirely different in the northern part of the country. In the northwestern Atacora Mountains, the mainly Somba population was dispersed, living in extended family compounds rather than multifamily villages. ${ }^{78}$ In the northeast, where there were a few small Bariba kingdoms, hierarchy was more pronounced. Jacques Lombard, one of the foremost ethnographers of the North, sums up Bariba social organization as a "system of domination imposed by the [Bariba] nobility." ${ }^{79}$ Because the French colonizers did not face threats from the Bariba authorities, they were able to graft their institutions on to traditional structures, turning traditional princes into chefs de cantons, instead of replacing them. As Glélé observes, in the eyes of the population, "the chefs de cantons of the regions of north and center, incarnated royal and traditional authority" and were thus more popular than the figureheads and usurpers of the South. ${ }^{80}$ However, these few remaining hierarchical structures affected less than 10 percent of the population. Overall, by the time mass electoral politics began, Benin had very weak traditional authority.

\section{Endurance of Social Structure}

Thus far we have considered social structures that politicians inherited in the 1950s. In the case of Benin, where traditional authority was severely undermined already by the early twentieth century, the weakness of contemporary local leaders will come as no surprise. Two decades of Mathieu Kérékou's Marxist dictatorship, featuring typical Marxist hostility to traditional rulers, further restricted social hierarchies. What is more surprising is how well the traditional and religious elites in Senegal have preserved their power for over half a century. Two complementary explanations of these elites' resilience are worth highlighting. First, both religious and traditional elites have cooperated with the ruling party consistently over the years. The symbiotic relationship between those in power and Senegalese local leaders became known as the "Senegalese social contract." ${ }^{\text {"Si }}$ Since local leaders were very useful

\footnotetext{
${ }_{77}$ Glélé 1969, 247, quoted in Banégas 2003, 326.

${ }^{78}$ Thompson 1963, 201.

${ }^{79}$ Lombard 1965, 37.

${ }^{80}$ Glélé 1969, 22.

${ }^{81}$ Cruise O’Brien 1992.
} 
for the governing elite, national politicians had few incentives to undermine the position of those who were helping them stay in power. Second, the weakness of the Senegalese state meant that any attempts to wrest power from local leaders would be difficult to execute in practice. For example, the National Domain Law of 1974, intended to place most land under the control of the state, failed to curtail the power of local elites to allocate land. ${ }^{82}$ In sum, the ongoing dependence of politicians on the mediation of local authorities, coupled with state weakness, created a propitious environment for local leaders to solidify their position.

The importance of Senegalese local elites and their comparative strength vis-à-vis their Beninese counterparts are evident in contemporary survey research. Rounds 3 and 4 of the Afrobarometer survey ${ }^{83}$ contain two questions that serve as good proxies for the power of local leaders, a reflection of their potential to serve as intermediaries. One question (Q32 in round 3) asks respondents to state how often during the course of the last year they turned for help or gave their point of view to different types of leaders (MPs, government councilors, political party officials, and religious and traditional rulers). This question is a good indicator because hierarchical ties and the power of local leaders are based on relationships of dependence that encompass all aspects of a person's life-material, social, and political. While few Beninese turn for help to their local leaders (only around 5 percent of respondents), the Senegalese are three to four times as likely to do so, with 23 percent of respondents often turning to religious leaders and 16 percent to traditional leaders. ${ }^{84}$ Question $49 \mathrm{i}$ (in round 4) asks respondents how much they trust traditional leaders. Again, the difference between Senegal and Benin is substantial. While 66 percent of Senegalese say that they trust traditional leaders "a lot," the percentage is much lower in Benin, standing at 33 percent. ${ }^{85}$

\footnotetext{
${ }^{82}$ Galvan 2004.

${ }^{83}$ Conducted in 2005 and 2008, respectively. Afrobarometer surveys can be found at afrobarometer.org.

${ }^{84}$ It is worth noting that it is not the case that the role played by religious and traditional elites in Senegal is played by different actors in Benin. The Afrobarometer survey asked about reliance on six different types of leaders. In Benin none of them even remotely approached (the highest level of reliance did not surpass 5.5 percent) the role played by traditional and religious leaders in Senegal.

${ }^{85}$ In Benin, the main Southern groups (Fon and Adja), where traditional hierarchy was destroyed, have much lower trust levels than the Bariba, which was the only group that had some traditional leaders remaining. The rates are 24 percent and 17 percent (for the two Southern groups, respectively) and 60 percent for the Northern Bariba.
} 


\section{Corresponding Modes of Political Mobilization}

\section{Electoral Mobilization in Benin}

The strength of local elites dictates electoral mobilization strategies that are available to politicians. In the absence of strong hierarchical ties in Benin, local leaders lack the influence to act as effective intermediaries between politicians and the populace. As expected in such cases, ethnic affiliations have been an important means of political mobilization since independence. ${ }^{86}$ Observers of the early rounds of elections note that appeals to tribal allegiance were common. ${ }^{87}$ To this day, the dominant view in the country is that a party wins votes based on the origin of its head, together with the ethnic identities of the party's candidates. Kouassi Degboé, among the most influential and oft-cited observers, argues that "in the 1995 legislative elections ethnic group affiliation was the fundamental basis of electoral expression. Ethnicity seems the focal point around which the electorate is constituted." 88

This "double-ethnic strategy," as it is commonly known in Benin, was often brought up by politicians whom I interviewed during the 2007 legislative elections. For example, Edgard Capo Chichi, a campaign coordinator for the presidential alliance, Forces Cauris pour un Bénin Emergent (FCBE), in the 15th electoral district of Cotonou, confirmed that ethnic considerations constitute the main electoral logic of political campaigns, including the choice of candidates. ${ }^{89}$ Dr. Djibril Debourou, an MP elected from the FCBE list in the 7th district, concurs that the two conditions that are a sine qua non for electoral success are the origin of the candidate and the identity of the party leader. ${ }^{90}$ Such views were repeated almost verbatim by several other politicians, including Robert Dossou (an FCBE candidate and former presidential candidate), Prof. Theodore Holo from Rennaisance du Benin (party of the former president Nicephore Soglo), and Ali Houdou from Parti Socialiste du Benin. ${ }^{91}$ Aurelien Housso, a former minister under President Soglo (RB), also stressed ethnic ties as the building blocks of electoral strategies. ${ }^{92}$ As he elaborates, in presidential elections, each group usually has its own candidate.

${ }^{86}$ Seely 2007, 197.

${ }^{87}$ See, for example, Decalo 1970; and Decalo 1973.

${ }^{88}$ Le Matinal, January 26, 2006.

${ }^{89}$ Author interview with Edgard Capo Chichi, Cotonou, Benin, March 27, 2007.

${ }^{90}$ Author interview with Djibril Debourou, Cotonou, Benin, April 3, 2007.

91 Author interview with Robert Dossou, Theodore Holo, and Ali Houdou, Cotonou, Benin, March 2, April 3, and April 4, 2007, respectively.

${ }^{92}$ Author interview with Aurelien Housso, Cotonou, Benin, April 5, 2007. 
While my interlocutors considered the use of intermediaries in Benin exceedingly rare, the Northeast, the only region with relatively strong local leaders, has always been an exception. This regional contrast was manifest from the earliest elections in the 1950s, when Beninese representatives to the French Assembly employed electoral strategies that mirrored their regional social structures. Sourou-Migan Apithy, a Southerner, commanded an explicit and direct ethnic vote, whereas Hubert Maga, a Northerner, relied on the chiefs to organize electoral support. ${ }^{93}$ In order to gain votes, Maga needed the consent of a few grands électeurs, including several ruling families and Fulani chiefs. ${ }^{94}$ As Decalo pointed out, "social cohesion around Hubert Maga is enforced by chiefs and royal princes." 95 Maga relied heavily on political brokers in small villages in the North, typically the village chief or the council of elders, who mobilized on his behalf. ${ }^{96}$ Maurice Glélé portrays well the degree of Maga's dependence on electoral intermediaries. As he describes it, Maga entered his political career as a "prisoner," linked to "certain grands électeurs from the North, who brought him their clientele at the price of substantial political and material advantages." 97 This pattern repeated itself almost fifty years later. Describing the inner workings of President Mathieu Kérékou's reelection campaign in 2001, Bierschenk reports that Kérékou's coordinator in the northern city of Parakou "did not forget the traditional peddlers of political influence, in particular the city's numerous mosques and their imams, who all received more or less significant sums of money from him during the election. ${ }^{98}$

\section{Electoral Mobilization in Senegal}

Unlike Benin, most of Senegal has been characterized by strong hierarchical ties, both in the 1950 s and at present, with many influential local leaders who could serve as intermediaries between politicians and the mostly illiterate population. Indeed, the use of intermediaries, rather than direct ethnic appeals, has been the dominant mode of electoral mobilization in Senegal. The concept of an intermediary is very well understood and so common in political discussion that the Senegalese have several words to refer to people serving such functions: porteurs

${ }^{93}$ Staniland 1973, 306.

${ }^{94}$ Staniland 1973, 307; Glélé 1969, 121.

${ }^{95}$ Decalo 1973, 451.

${ }^{96}$ Decalo 1973, 453.

${ }^{97}$ Gléle 1969,121 . For example, one of these intermediaries was rewarded with the position of minister of economy and commerce (Glélé 1969, 247).

${ }^{98}$ Bierschenk 2006, 560. 
de voix (literally "vote carriers"), the most frequently used term, but also "electoral relays" (relais électoraux), vectors (vecteurs), and intermediaries (intermédiaires). Scholars of Senegalese politics have extensively documented the political involvement of communal brokers, such as the marabouts or the toorodo oligarchy in the Fouta (Senegal River Valley) region. ${ }^{99}$ The only part of Senegal where politicians historically struggled to find suitable intermediaries, given the weakness of the traditional leadership, was the Casamance. ${ }^{100}$

A rich body of work documents the continuous use of intermediaries by politicians and even by the French administration since the onset of mass politics in the 1950s. Cruise O'Brien gives many examples of intermediary involvement in historic elections, most notably, to vote against independence from France in $1958 .{ }^{101}$ That was the primary electoral strategy of the two main parties in the 1950s: the Bloc Démocratique Sénégalais (BDS) and the French Socialist Party (SFIO). As Boone notes in her case study of the Groundnut basin, "the BDS and SFIO tried to outdo each other in courting Mouride and Tijan [religious] leaders." ${ }^{102}$ After independence, ties with intermediaries, especially the religious leaders, were crucial for President Senghor and his Union Progressiste Sénégalaise party. ${ }^{103}$ As Boone argues, Senghor's electoral success relied on his use of "established rural powerbrokers."104 This tactic was certainly not unusual since, as Boone notes, no party has ever adopted a different strategy for mobilizing electoral support. ${ }^{105}$ The same practice was continued in the 1980s and 1990s by Senghor's successor, Abdou Diouf. ${ }^{106}$ As Young and Kanté noted, at the basis of Diouf's electoral success "lay networks of clientelistic linkages joining the president and party to civil society through the intermediation of a host of marabouts and local patrons." 107

During the run-up to the February 2007 election my interviewees indicated that intermediaries are still used frequently in electoral politics. Members of the ruling Parti Démocratique Sénégalaise (PDS)

\footnotetext{
${ }_{99}$ Beck 1997; Beck 2001; Beck 2008; Galvan 2001; Foltz 1969; Diop 2002; Diop, Diouf, and Diaw 2000; Cruise O’Brien 1971; Cruise O’Brien 1975; Coulon 1988; Young and Kanté 1991; Villalón 1994; Boone 2003.

${ }^{100}$ Beck 2008; Boone 2003.

${ }^{101}$ Cruise O’Brien 1971.

102 Boone 2003, 62.

${ }_{103}$ Schaffer 1998, 107. Note that the UPs became successor to the earlier Bloc Démocratique Sénégalais (BDS).

${ }^{104}$ Boone 2003, 60.

105 Boone 2003, 60.

106 See, for example, Zuccarelli 1988, 165; Schaffer 1998, 107.

${ }^{107}$ Young and Kanté 1991, 72.
} 
talked freely about their party's reliance on local powerbrokers, especially religious leaders. For example, Babacar Gaye, the vice president of the National Assembly and a close associate of President Wade, explains that Wade's campaign "identifies powerful people in a community" and approaches them (with rewards) to enlist their support. ${ }^{108}$ Similarly, on the opposition's side, a spokesman for a presidential candidate Idrissa Seck also admitted that his boss acquired some support of local leaders, which, as he added, was not free. ${ }^{109}$ Samir Abourizk, a leader of a small party, Democratie Citoyenne, who eventually joined the president's electoral alliance, argued that "all parties during elections are obligated to look for support among religious leaders." 110 Talking specifically about the 2007 campaign, he added that in his view, "all candidates cultivate links with religious chiefs." 111 An opposition MP from LD/MPT, Opa Diallo, likewise believes that all parties use intermediaries, whereas many other opposition politicians insisted that it is mainly a strategy of the incumbent and decried it as influence trafficking. ${ }^{12}$ Semou Pathe Gueye, from Parti de l'independence et du travail (PIT), criticized President Wade for wanting to "control lower classes by local intermediaries." 113 He added that "Wade analyzed very well the country's network of influence," conceding that the president and his entourage are very skilled at this practice. ${ }^{114}$

The search for intermediaries was also freely discussed in the media by those in President Wade's entourage. The way Thierno Ousmane Sy (son of Minister of Justice Cheikh Tidiane Sy) described this quest on behalf of President Wade is highly illustrative:

\begin{abstract}
We [those in power] ended up identifying all the vote carriers (porteurs de voix) in the country, all who were likely to make us win in all localities and in all categories and social classes of the society. These vote carriers, at this point, we studied them [and] we know all of them. Their habits, their tastes, their strengths and their weaknesses. ${ }^{115}$
\end{abstract}

There is a remarkable consensus among politicians from various parties about who such intermediaries are in different parts of the country.

\footnotetext{
${ }^{108}$ Author interview with Babacar Gaye, Dakar, Senegal, December 1, 2006.

${ }^{109}$ Author interview with Mr. Bokum, Dakar, Senegal, February 14, 2007.

${ }^{110}$ Author interview with Samir Abourizk, Dakar, Senegal, October 16, 2006.

${ }^{111}$ Author interview with Samir Abourizk, Dakar, Senegal, October 16, 2006.

${ }^{112}$ Author interviews with Opa Diallo, Madior Diouf, Mamadou Ly, and Ibrahima Sene, Dakar, Senegal, November 2006, March 1, 2007, and February 13, 2007, respectively.

${ }_{113}$ Author interview with Semou Pathe Gueye, Dakar, Senegal, March 1 and 3, 2007.

${ }^{114}$ Author interview with Semou Pathe Gueye, Dakar, Senegal, March 1 and 3, 2007.

${ }^{115}$ Le Quotidien, March 3, 2007.
} 
As Cheikh Seye, from Parti Socialiste (PS), explains, "[W]e know who are the vote carriers, we know who can make the masses vote, it is very objective, we know who weighs heavily." 116 As Seye indicates, politicians across the political spectrum tend to analyze social structure, with its networks of dependence, in similar ways, and they identify the same people as potentially influential. For example, in the town of Mbour (in central Senegal) I interviewed local politicians representing all major political forces during the week before the 2007 presidential election. ${ }^{117}$ All of them identified religious leaders as the main players. More importantly, those in search of intermediaries were trying to acquire them from across the identity spectrum. It is not the case that President Wade, a Mouride, seeks support only in the Mouride brotherhood. As the PDS's campaign chief in the department of Mbour, Magatte Diop, summed up, President "Wade has tentacles in all religious families" in Senegal. ${ }^{118}$

The use of intermediaries by politicians and parties is accompanied by a belief that they indeed have an impact on voters' electoral choices. Mbaye-Jacques Diop, the fourth person in command in Senegal, ${ }^{119}$ explains: "when people vote, the national figure matters, but you vote above all for the local figure" (le personage local). ${ }^{120}$ A member of Idrissa Seck's Rewmi Party observed that when it comes to voting "people listen to those who feed them." 121 Babacar Gaye from the ruling PDS explained that intermediaries are useful because they can influence scores of people. ${ }^{122}$ Local leaders of LD/MPT in Mbour reported that to get votes they work with religious dignitaries, customary and village chiefs, because in their impoverished area "everyone is dependent" and local leaders often influence how people vote. ${ }^{123}$

There is even evidence that after the 2007 election, President Wade attributed his high vote share in the department of Mbacke, including the capital of the Mouride brotherhood, the holy city of Touba, to the marabouts' backing. Wade arrived in Touba within twenty-four hours of the electoral results to thank the religious establishment for their support.

${ }_{116}$ Author interview with Cheikh Seye, Dakar, Senegal, December 18, 2006.

${ }_{117}$ Author interviews with Ibrahima Faye (LD/MPT), Modou Diop (LD/MPT), Tidiane Diop (LD/ MPT), Magatte Diop (PDS) and Ousman Sow (TDS), Mbour, Senegal, February 20, 2007.

${ }_{118}$ Author interview with Magatte Diop, Mbour, Senegal, February 20, 2007.

${ }^{119}$ President of the Conseil de la Republique, an institution akin to the upper house of parliament.

${ }^{120}$ Author interview with Mbaye-Jacques Diop, Rufisque, Senegal, March 1, 2007.

${ }_{121}$ Author interview with Mamadou Sombre, Dakar, Senegal, February 14, 2007.

${ }^{122}$ Author interview with Babacar Gaye, Dakar, Senegal, November 29, 2006.

${ }^{123}$ Author interviews with Ibrahima Faye, Modou Diop, and Tidiane Diop, Mbour, Senegal, February $20,2007$. 
In a meeting with the Khalifa général of the Mouride brotherhood, Wade proclaimed: "This victory is yours. I come to show you my gratefulness." ${ }^{24}$ The president then went on to reassure the Khalifa that he would uphold his end of the deal: "Inchallab [God willing], the first projects during my second term will take place in Touba." 125

While it is easy to document the widespread use of intermediaries by politicians, the reader will wonder whether these individuals actually influence the voting behavior of their followers. Two different surveys give credence to the claim. A study conducted in 1999 in the departments of Thiès and Diourbel by Gercop, a group of researchers from the (Senegalese) University of Saint-Louis, found that 38 percent of their respondents admitted to following voting orders (consignes de vote) from religious leaders. ${ }^{126}$ The 2005 Afrobarometer survey in Senegal also asked respondents who (if anyone) can influence their political choices (Question 88a_Sen). Twenty-three percent of Wolof respondents reported that they are influenced a lot by their religious leader. ${ }^{127}$ The self-reported influence of intermediaries is thus nonnegligible and, considering the sensitivity of such a question, may be even higher.

There is evidence not only that people are influenced by their religious leaders but also that the tighter the tie, the more they follow such leaders' suggestions. A comparison of the two largest Senegalese Sufi brotherhoods, the Mouridiyya and Tijaniyya, illustrates this variation. The relationship between Mouride disciples and their leaders is uniformly regarded by scholars and politicians alike as tighter than the one among the Tijanis, because of the Mouride leaders' greater control of material resources and the brotherhood's more stringent norms of obedience. ${ }^{128}$ We would thus expect Mourides to wield more electoral influence over their followers. Indeed, in the Afrobarometer survey over

${ }^{124}$ Diallo 2007.

${ }^{125}$ Diallo 2007.

${ }^{126}$ Etude sur le comportement électoral dans les régions de Thiès et Diourbel, May 1999. The sample size was 4877 (2900 in the department of Thiès and 1977 in Diourbel).

${ }^{127}$ The difference between the two surveys might be due to the fact that the two departments surveyed by Gercop are in the heartland of the Senegalese Muslim brotherhoods and thus the larger role of religious leaders is not inconsistent with our expectations. The Afrobarometer surveyed all regions in Senegal, including zones where the dominant type of intermediary comes from traditional and not religious elites (thus we would not expect voters to turn to religious leaders in those areas). I limited the sample to Wolof respondents to make it more comparable to the Gercop study, since the Wolof are most likely to be influenced by this particular type of intermediary. The sample still contains Wolofs outside the groundnut basin, where religious intermediaries are weaker.

${ }^{128}$ For a detailed comparison of the relations between the Tijani and Mouride leaders and their dependents, see Behrman 1970, esp. 62, 63, 68; Villalón 1996, 119-20; Coulon 1981, 104-5; Cruise O’Brien 1971, 86, 91-96; Cruise O'Brien 1975, 74. 
twice as many Mourides as Tijanis say that their electoral choices are influenced "a lot" by their religious leaders. ${ }^{129}$

Intermediaries transform electoral politics because many politicians express an interest in acquiring intermediaries from across the ethnic spectrum. Likewise, intermediaries also show their willingness to support non-coethnics. An anecdote recounted to me by Madieyna Diouf, one of the top leaders of Alliance des Forces de Progrès (AFP), illustrates well the fluidity of local support for different candidates. Diouf remembers that when his boss, the leader of AFP, Moustapha Niasse, campaigned in his home region of Kaolack, a local Tijani marabout in one village asked for money for the construction of a mosque. Niasse (a fellow Tijan) gave him around 5 million francs CFA (US \$10,000). ${ }^{130}$ When Niasse visited the village again four days before the election, the marabout asked him for more money. Later that day Niasse sent another 10 million francs CFA via a messenger. But the news of the transaction got out and the ruling party, PDS, contacted the same marabout and promised him 100 million francs CFA. Fifty million was paid up front and the remaining fifty million was to be paid after the election if the marabout delivered the villagers' votes. Diouf admitted that these tactics undoubtedly worked, since President Wade (a Mouride) won overwhelmingly in that village.

A few examples will further illustrate this point. The 1951 legislative election to the French National Assembly pitted Léopold Senghor, a Catholic, against a Muslim, Lamine Guèye. To access the substantial rural electorate, both candidates were seeking support from Muslim dignitaries, including the two most prominent ones, Serigne Falilou Mbacké, the khalifa général of the Mouride brotherhood, and Ababacar Sy, the khalifa général of the Tijian brotherhood. According to Senegalese historian E1 Hadj Ibrahima Ndao, though the two religious leaders were initially more predisposed to their fellow Muslim, Lamine Guèye, they were able to extract promises of higher future material rewards from the Catholic Senghor. ${ }^{131}$ After the two most prominent marabouts in Senegal issued a voting order to their followers to support Senghor, he beat Lamine Guèye by a margin of more than a two to one. ${ }^{132}$ Instances of intermediaries switching their support from their in-group member to a politician from a different background are legion. Take the example of a religious leader, Serigne Mamoune Niasse,

\footnotetext{
${ }^{129}$ In the Gercop survey a greater number of Mourides than Tijanis (by 6 percentage points) follows voting orders.

${ }^{130}$ Author interview with Madieyna Diouf, Dakar, Senegal, April 2007.

131 Ndao 2003, 132.

${ }^{132}$ Ndao 2003, 138.
} 
who supported his fellow Tijan, Idrissa Seck, during the 2007 presidential election until being offered a ministerial position (without portfolio) by the Mouride incumbent, President Wade. ${ }^{133}$

Even when intermediaries support their group member in a given election, this is not a stable practice over time. For example, while Modou Kara Mbacke, another well-known marabout, supported President Wade in 2007, he had supported the Tijani incumbent Abdou Diouf against Wade in 2000, when his fellow Mouride had been a less prosperous opposition candidate. Indeed, as Kara's right-hand man, Abbas Bâ, explained, in choosing which candidate to support, "we go towards power." 134 PDS's Babacar Gaye also suggests that intermediaries are looking above all for the highest bidder. As he explains, "Intermediaries do not have much consideration for everyone; you have to have the means. Relays prefer people with money." 135 In this respect, intermediaries' allegiances are markedly different from what we would expect if they were driven merely by ethnic considerations.

\section{Electoral Outcomes}

As the preceding paragraphs outlined, politicians in Senegal and Benin followed qualitatively different mobilization strategies. Their chosen modes of mobilization, in turn, had implications for electoral outcomes, namely, the presence or absence of identity-based voting blocs. Direct mobilization of ethnic groups simply translates ethnic identity into vote choice, resulting, not surprisingly, in identity-based voting blocs. Electoral intermediaries, in turn, deliver voters to politicians across ethnic lines, helping parties and candidates build diverse electorates. ${ }^{136}$ In portraying the degree of ethnic politics in the electoral arena, I now refer to some of the most widely used indicators, such as the existence of ethnic candidates or parties and the degree of ethnic voting.

\section{BENIN}

In Benin, where there were no suitable intermediaries and electoral mobilization took place along ethnic identities, electoral competition resulted in a substantial degree of ethnic politics. Parties demonstrate

\footnotetext{
${ }^{133}$ Diop 2006.

${ }^{134}$ Author interview with Abbas Bâ, Dakar, Senegal, February 26, 2007.

${ }^{135}$ Author interview with Babacar Gaye, Dakar, Senegal, November 29, 2006.

${ }^{136}$ Even though opposition candidates and parties are at a disadvantage vis-à-vis the incumbent, they still manage to get some intermediaries across different groups. Incumbents do not acquire all intermediaries. For example, Beck 2008 notes that there is a certain degree of jockeying for position between different religious leaders. Even within one maraboutic family, it is not uncommon for more senior leaders to support the incumbent and for the junior leader to back opposition candidates.
} 
distinct ethnic compositions, and most of them receive the majority of their support from a single group. According to contemporary observers, Benin's main parties have a distinct ethnic character, with the Renaissance du Benin (RB) associated with the Fon (South-Central Benin), Parti Social Démocrate with Adja (Southwest), and Parti pour le Renouveau Démocratique with Goun and some Yoruba around Porto-Novo in the Southeast. ${ }^{137}$ These observations are borne out by the 2005 and 2008 Afrobarometer surveys, which provide individuallevel data on voters' identity and political allegiance. For example, the 2005 data show that the PSD and its leader, Bruno Amoussou, has a predominantly (79 percent) Adja base, RB and Soglo have mainly Fon supporters (86 percent), and the PRD and Adrien Houngbedji have a mostly (80 percent) Fon electorate, but mostly from the distinct Goun $\operatorname{subgroup}^{138}$ (see Table 1). Yayi Boni is the only major national politician in the multiparty era that has a more varied, albeit not fully representative, electorate than his main rivals. ${ }^{139}$ An index that measures the association between ethnic identity and party preference (CVELI), calculated with individual-level data from Afrobarometer, indicates that 41 percent of vote choice in Benin can be predicted by ethnicity alone. ${ }^{140}$ Moreover, 80 percent of the Afrobarometer respondents revealed a preference for supporting a candidate of their ethnicity. ${ }^{141}$

Ethnoregional electoral parties emerged in Benin almost instantly after the introduction of mass politics. Already in the 1950s, while Benin was still under French colonial rule, there was an ethnoregional party system, composed of three regional blocs. ${ }^{142}$ In this three-party system, Sourou-Migan Apithy controlled the Goun and Yoruba Porto Novo area, which is dominated by Houngbedji's PRD in the current era, Justin Ahomadegbe represented the Fon-dominated Southwest, now Soglo's base, and Hubert Maga controlled the North. Accordingly, some of the earliest postindependence political contests show ethnically based electoral results. Unfortunately, we do not have individual-level

\footnotetext{
${ }^{137}$ E.g., Bierschenk 2006, 567. See also Afrobarometer Briefing Paper no. 17, 2005, 7.

${ }^{138}$ The Beninese census does not differentiate between Goun and Fon. Therefore, PRD's supporters are (misleadingly) classified as Fon. Battle and Seely 2007 cross-check PRD's supporters' geographic location with fine-grained identity data for the relevant localities, and they indeed confirm that the vast majority of them are Goun (p. 16).

${ }^{139} \mathrm{It}$ is worth pointing out that, in contrast to other candidates, Yayi Boni benefits from a mixed ethnic background (Mayrargue 2006, 164). While his mother is a Bariba (Northerner), his father is a Nago (Yoruba from the South). He was born a Muslim and became a Christian. Moreover, Yayi is married to a Southerner from a prominent Ouidah family.

${ }^{140}$ Dowd and Driessen 2008; see also Figure 1 in this article.

${ }^{141}$ Seely 2007, 197.

${ }^{142}$ Staniland 1973; Decalo 1970; Decalo 1973.
} 
TABLE 1

Ethnic Composition of the Electorates of Main Presidential CANDidates in Benin ${ }^{a}$

\begin{tabular}{|c|c|c|c|c|c|}
\hline \multirow[b]{2}{*}{ Ethnic Group } & \multirow{2}{*}{$\begin{array}{c}\text { Group's } \\
\text { Share of the } \\
\text { Population } \\
\text { (\%) }\end{array}$} & \multicolumn{4}{|c|}{ Candidates } \\
\hline & & $\begin{array}{c}\text { Soglo }(R B) \\
(\%)\end{array}$ & $\begin{array}{c}\text { Houngbedji } \\
\text { (PRD) } \\
(\%)\end{array}$ & $\begin{array}{c}\text { Amoussou } \\
\text { (PSD) } \\
(\%)\end{array}$ & $\begin{array}{c}\text { Yayi } \\
\text { (Unaffiliated) } \\
\text { (\%) }\end{array}$ \\
\hline Fon & 42 & 86 & 80 & 11 & 34 \\
\hline Adja & 16 & 8 & 8 & 79 & 4 \\
\hline Bariba & 10 & 6 & 2 & 4 & 22 \\
\hline Yoruba & 12 & 0 & 8 & 2 & 19 \\
\hline Ditamari & 7 & 0 & 1 & 0 & 4 \\
\hline Peul & 5 & 0 & 0 & 0 & 3 \\
\hline
\end{tabular}

SOURCE: Afrobarometer 2005, round 3.

aBased on question 99 from Afrobarometer 2005, asking respondents, "If the presidential elections were held tomorrow, who (a candidate from which party) would you vote for?" (round 3; $N=1198$ ). I include candidates who received over 5 percent of the vote in the 2006 presidential election. Together the four candidates received over 80 percent of the vote. Please note that since the Afrobarometer survey preceded the election by about ten months, around 40 percent of respondents stated that they did not know how they would vote and a further 16 percent indicated that they wanted to vote for the then incumbent, Mathieu Kérékou, who was barred from running for reelection due to presidential term limits. Ethnic group membership is based on Q79. Group's share of the population size is based on the group's share of the sample (rather than the population as a whole). Since it is an equal probability sample, it should very closely approximate groups' share of the population. The same question was repeated in round 4 of Afrobarometer 2008 survey and it yielded very similar results. These additional data are available from the author upon request.

data for that time period, as surveys of electoral preferences were virtually nonexistent. Any analysis of voting patterns thus has to grapple with ecological inference problems. Despite this limitation, we can still draw some conclusions from available sources.

In the 1960 General Council elections Apithy's Parti des Nationalistes Dahoméens won all forty-five seats in the Goun/Yoruba-dominated Southeast, whereas Ahomadegbe's Union Démocratique Dahoméenne won the majority of seats in the Fon-dominated Center and Southwest. Neither party won any seats or more than a handful of votes in the North. ${ }^{143}$ Most strikingly, Maga's Rassemblement Démocratique Dahoméen won all of the seats in the North without contesting any constituencies in the South or Center of the country. ${ }^{144}$ We can

${ }^{143}$ Decalo 1973, 454.

${ }^{144}$ Decalo 1973, 454. 
therefore ascertain that the electoral bases of the PND and the UDD differed in ethnic terms from the RDD. Given that the North and South of Benin have completely different ethnic compositions, a few facts emerge. RDD had no electoral support from either Fon or Adja, the country's two largest ethnic groups, since the party won votes only in the North, where there are virtually no Fon (under 3 percent of the population) or Adja (under 1 percent). ${ }^{145}$ Similarly, we can establish that the PND had no support from the Bariba, Dendi, or Ottomari, who together constitute around 17 percent of the national population. These groups reside exclusively in the North-they total less than 1 percent in the rest of Benin ${ }^{146}$ - and the PND did not win a single vote in the North.

The same pattern emerged during the 1960 presidential elections and then was repeated ten years later in the 1970 elections. As Decalo argues, the ethnic-oriented results of the 1970 election "vividly confirmed the tribal-regional basis of power." ${ }^{147}$ These ethnoregional electoral patterns were remarkably sticky, as the percentage of votes each candidate obtained in his core area in 1970 was virtually the same as in 1960.

Remarkably, the first multiparty elections following Mathieu Kérékou's twenty-year Marxist dictatorship bore a striking resemblance to the pre-1972 ethnic political dynamics. Once again, a system of ethnoregional parties built around regional leaders emerged, as evidenced by the Afrobarometer data. This is despite the new Political Party Charter's stipulation that parties could not be formed according to ethnic or other corporate principles but must have a "national character."148 Each of the ethnoregional blocs has its presidential candidate. Just as a Goun (Porto-Novo) bloc had coalesced around Apithy in the 1950s and 1960s, it reemerged in the 1990s, controlled first by Tevoedjre and then by Houngbedji. Likewise, one can see Soglo's Fon base as the continuation of Ahomadegbe's southwestern base in the 1960s. Finally, the North remains the "residual" bloc, having never been incorporated into any of the southern ethnic blocs.

Are the electoral patterns among the Bariba in the Northeast, where local leadership remained stronger than elsewhere in Benin, any different from the rest of the country? ${ }^{149}$ In presidential elections, the

\footnotetext{
${ }^{145}$ National Statistic Bureau, Institut National de la Statistique et de l'Analyse Économique (INSAE), Cotonou, Benin.

${ }^{146}$ INSAE.

${ }_{147}$ Decalo 1973, 470.

148 Article 4, Law No.90-025, August 13, 1990 (cited in Battle and Seely 2007, 4-5).

149 One complication in assessing how the Bariba should have behaved in presidential elections is that, unlike in the case of Senegal, my theory and the affinity voting theories would make similar predictions for four out of the five elections.
} 
Bariba seem more amenable than some of the other relatively small groups, such as the Adja or the Goun, to support non-coethnics. In the first three presidential elections since the return to multiparty democracy, the Bariba did not promote a Bariba candidate. This might not seem surprising, as it is a small group with little electoral weight, but other groups of comparable size have supported ethnic candidates. The Bariba voted for the incumbent or the eventual winner in all contests, but in all cases this also happened to be a Northerner, making it impossible to verify whether they would be willing to support a Southerner.

\section{Electoral Outcomes in Senegal}

Consistent with intermediary-type politics, we do not observe ethnic candidates or parties in Senegal. As Makhtar Diouf sums up: "[T]he Senegalese landscape has never been traversed by ethnic or religious cleavages, not in the past, not in the present." 150 This is the perception that both Senegalese voters and academics have of the political landscape, but more importantly it is clearly supported by the electoral data. Individual-level data from the 2002 Afrobarometer survey provide the best evidence that candidates' and parties' support is not determined by identities, be they ethnicity, religion, or brotherhood. Respondents' choices from the 2000 election show that identity factors are poor predictors of voting. The ethnic composition of Abdoulaye Wade's winning electorate is very similar to that of his main rivals. Similarly, his scores among each ethnic group are highly proportional to each group's size, with no single group dominating his electorate (see Table 2). Similarly, candidates' vote shares among Muslims and Catholics, as well as among the main brotherhoods, appear evenly distributed and proportional to the group size (see Tables 3 and 4). When Wade, a Mouride, ran against Diouf, a Tijan, their levels of support among the two groups were almost indistinguishable. Diouf, a Tijan, got 39 percent of his votes from Tijanis, and 41 percent from Mourides. Wade, a Mouride, got 45 percent of his votes from Mourides and 39 percent from Tijianis. ${ }^{151}$

${ }^{150}$ Diouf 1994, 44-45.

${ }^{151}$ These findings are fairly robust. The results of the 2001 legislative elections similarly highlight the lack of discernible ethnic (or other identity) voting patterns. Individual-level data from Round 2 Afrobarometer survey (2002) show that the three main parties, Parti Socialiste (PS), Parti Démocratique Sénégalais (PDS), and Alliance de Forces de Progrès (AFP) enjoyed comparable levels of support among the country's Muslims and Catholics, in proportion to their overall scores in that election. The same can be said about the breakdown of their support among Mourides and Tijanis or among the main ethnic groups. Most importantly, neither party relied heavily on support from any given group (or coalition of groups). Moreover, data gathered in round 3 of the Afrobarometer survey, conducted in 2005 , as well as in round 4 (2008) yield very similar patterns as are found in round 2. These additional data are available from the author upon request. 
TABLE 2

Ethnic Composition of the Electorate of Three Main Presidential Candidates in Senegal ${ }^{\mathrm{a}}$

\begin{tabular}{|c|c|c|c|c|}
\hline \multirow[b]{2}{*}{ Ethnic Group } & \multirow{2}{*}{$\begin{array}{c}\text { Groups's } \\
\text { Share of the } \\
\text { Population } \\
\text { (\%) }\end{array}$} & \multicolumn{3}{|c|}{$\begin{array}{l}\text { Candidates' Share of Their Total Vote Received } \\
\text { from a Given Group }\end{array}$} \\
\hline & & $\begin{array}{l}\text { Wade (PDS) } \\
\text { (\%) }\end{array}$ & $\begin{array}{l}\operatorname{Diouf}(P S) \\
\quad(\%)\end{array}$ & $\begin{array}{l}\text { Niasse (AFP) } \\
\text { (\%) }\end{array}$ \\
\hline Wolof & 42 & 42 & 43 & 42 \\
\hline Pulaar & 28 & 30 & 26 & 28 \\
\hline Serer & 13 & 11 & 20 & 13 \\
\hline Mandika & 5 & 5 & 3 & 5 \\
\hline Diola & 5 & 4 & 4 & 5 \\
\hline
\end{tabular}

SOURCE: Afrobarometer 2002, round 2.

${ }^{\text {a }}$ These candidates gathered together 90 percent of the vote. It is based on a question $87 \mathrm{D}-\mathrm{SEN}$, "Who did you vote for in the 2000 presidential election?" Membership in an ethnic group is based on Q96A-SEN. Group's share of the population size is based on the group's share of the sample (rather than the population as a whole). Since it is an equal probability sample, it should very closely approximate groups' share of the population.

TABLE 3

Religious Composition of the Electorate of Three Main Presidential Candidates in Senegal ${ }^{a}$

\begin{tabular}{lcccc}
\hline \hline & Group's & & \multicolumn{2}{c}{ Candidates' Share of Their Total Vote Received } \\
& Share of the & \multicolumn{3}{c}{ from a Given Group } \\
\cline { 3 - 5 } & Population & Wade (PDS) & Diouf (PS) & Niasse (AFP) \\
Religious Group & $(\%)$ & $(\%)$ & $(\%)$ & $(\%)$ \\
\hline Muslims & 95 & 93 & 91 & 93 \\
Catholics & 4 & 5 & 9 & 5 \\
\hline
\end{tabular}

SOURCE: Afrobarometer, round 2 (2002).

${ }^{a}$ These candidates gathered together 90 percent of the vote. It is based on a question $87 \mathrm{D}-\mathrm{SEN}$, "Who did you vote for in the 2000 presidential election?" Religious membership is based in Q85. Group's share of the population size is based on the group's share of the sample (rather than the population as a whole). Since it is an equal probability sample, it should very closely approximate groups' share of the population.

Using their index CVELI, Down and Driessen estimate that only 11 percent of vote choice in Senegal can be predicted by ethnicity (compared with Benin's 41 percent). Working with the same data, Cheeseman and Ford calculated an index of ethnic polarization (the extent to which support for a given party varies among a country's ethnic groups) and ethnic diversity (the range of ethnic groups represented within different 
TABLE 4

Brotherhood Composition of the Electorate of Three Main

Presidential Candidates in Senegal ${ }^{\mathrm{a}}$

\begin{tabular}{lcccc}
\hline \hline & Group's & \multicolumn{3}{c}{ Candidates' Share of Their Total Vote Received } \\
from a Given Group \\
\cline { 3 - 5 } Sufi (Muslim) & $\begin{array}{c}\text { Share of the } \\
\text { Population }\end{array}$ & Wade (PDS) & Diouf (PS) & Niasse (AFP) \\
Brotherhood & $(\%)$ & $(\%)$ & (\%) & (\%) \\
\hline Mouride & 40 & 41 & 45 & 37 \\
Tijan & 39 & 39 & 39 & 49 \\
\hline
\end{tabular}

SOURCE: Afrobarometer 2002, round 2.

${ }^{a}$ These candidates gathered together 90 percent of the vote. It is based on a question $87 \mathrm{D}-\mathrm{SEN}$, "Who did you vote for in the 2000 presidential election?" Membership in a religious brotherhood is based on Q85A-SEN. Group's share of the population size is based on the group's share of the sample (rather than the population as a whole). Since it is an equal probability sample, it should very closely approximate groups' share of the population.

parties). ${ }^{152}$ Comparatively speaking, Senegal has one of the lowest polarization levels among African countries ( 0.13 on a scale between 0 and 1 ) and high diversity (0.7), and the authors conclude that ethnicity is not a significant factor in influencing party affiliation.

As in Benin, the results for Senegal demonstrate a continuation of electoral outcomes since the onset of mass politics. Already in the 1950s, political parties were not confined to ethnic blocs. Even in the absence of individual-level data, aggregate data from early elections highlight a few features incompatible with ethnic politics. During the 1957 elections to the territorial assembly, Leopold Sedar Senghor, a Catholic Serer, gained support for his Bloc Populaire Sénégalais (BPS) throughout the country, winning seats even in areas where there are no native Serer or Catholics. After independence, President Senghor actually enjoyed the highest levels of support in regions dominated by non-Serer Muslims. Similarly, President Diouf won with highest electoral margins in peripheral regions dominated by non-coethnics. ${ }^{153}$ In 2007, President Wade enjoyed very high electoral support in many areas, especially in eastern Senegal, where there are few fellow Mourides or Wolofs. Subnationally, the only exception to the generally successful cross-ethnic political integration is Casamance, where, as noted above, hierarchical ties and local leadership traditionally have been weak. Since 1982, the region, home to the Diola and

${ }^{152}$ Cheeseman and Ford 2007.

${ }^{153}$ Beck 2008, 2. 
Balant groups, has been the site of an ethnic rebellion and a separatist movement, Mouvement de Forces Democratiques de Casamance. ${ }^{154}$

\section{Alternative Explanations}

First, it is important to point out that the absence of ethnic politics in Senegal cannot be attributed to the lack of the social salience of ethnicity. Ethnic categories in both Senegal and Benin are regularly used by people to describe themselves and others, and they are also used in official documents, such as a census. They all have social meaning and markers, such as names, rituals, or stereotypes, attached to different identities. ${ }^{155}$ As Diouf points out, among most Senegalese there exists a "certain dose of ethnocentrism: one has a very flattering auto-portrait of one's own ethnic group" and one paints portraits of other ethnic groups "made of prejudices." 156 A study commissioned by UNESCO found that, for example, the Wolof view the Tukulor as overly conservative, whereas the Tukulor and other ethnic groups describe the Wolof as loud (gueulard), proud, materialistic, and deceitful. ${ }^{157}$

But might it be in politicians' interests to mobilize different identities instead of ethnicity? Advocates of institutionalist arguments suggest that politicians will mobilize along a cleavage that creates groups closest in size to the minimum winning coalition at a given level of competition, national in the case of former French colonies. ${ }^{158}$ In this respect, Senegalese politicians have other identity cleavages that they could activate. Just as in Benin, in addition to ethnicity, there are other socially salient identities, including religion and brotherhood affiliation, which could be mobilized by political entrepreneurs. Brotherhood affiliation in Senegal is highly socially salient. There is a marked variation in religious practice and celebration, with distinct pilgrimages and holy places

${ }^{154}$ For more detail on the ethnic rebellion, see de Jong 2005; Faye 1994; and Lambert 1998.

${ }^{155}$ For example, certain family names in Senegal, as in Benin, are associated with different ethnic groups: Bâ or Diallo would be immediately identified as Peul.

${ }^{156}$ Diouf 1994, 61.

${ }^{157}$ Diouf 1994, 57. For other ethnic stereotypes, see also Smith 2006; or Lambert 1998, 596. And on the manifestations of Haalpulaar (Peul and Tukulor) identity, see McLaughlin 1995. Some additional stereotypes are based on the most common occupations of different ethnic groups: the Wolof are traditionally merchants, the Peul are pastoralists, the Tukulor are sedentary agriculturalists, and the Serer and Lebou are fisherman. Moreover, ethnic groups have their ethnic homelands. Just as in Benin Abomey and its surroundings are the Fon heartland, or the Borgu is Bariba territory, the Senegal River Valley is home to the Tukulor, Casamance is considered the "Diola country" (pays Diola), Sine-Saloum is the heart of the Serer homeland, and much of central Senegal is pays Wolof. For detailed data on ethnic composition of different regions, see Diouf 1994, 33-40.

${ }^{158}$ Posner 2005; Chandra 2004. 
for different Sufi orders. ${ }^{159}$ People display allegiance to their brotherhoods by hanging pictures of religious leaders or of the founders of the respective brotherhoods. Many of my interviewees invoked common stereotypes about members of the two largest brotherhoods. For example, the Tijanis describe the Mourides as loud, boisterous, and ostentatious, while portraying themselves as calm, discreet, and modest.

Given the plethora of social markers, politicians could in principle easily appeal to brotherhood or ethnic affiliation in their political campaigns, just as their counterparts do across Africa. While no ethnic group or brotherhood constitutes an outright majority, ethnic or religious groups in Senegal are no more fragmented than in Benin: the Wolof in Senegal constitute around 43 percent of the population, similar in size to the Fon in Benin, whereas brotherhood divisions create the largest group close to the desired 50 percent. Nevertheless, as the Senegalese electoral data indicate, none of the three most socially salient identities (ethnicity, brotherhood affiliation, or religion) structures political competition (as demonstrated in Tables 2, 3, and 4). Nor do we find coalitions of different ethnic groups. It is thus not the case that Senegalese politicians do not mobilize along ethnic lines because they choose to activate a different identity cleavage, even though they could feasibly do so.

Finally, it is worth pointing out that electoral strategies in Benin do not follow closely the predictions of the minimum-winning coalition. It would be more advantageous for southern politicians to activate the "southern" identity, a label that is socially very salient, ${ }^{160}$ rather than a Fon, Adja, or Yoruba ethnic identity. If they followed this logic, Southerners could capture the majority of the electorate (about two-thirds) and they could have a permanent hold on the presidency. Instead, a southern politician has served only one five-year presidential term (Soglo 1991-96) since the introduction of multiparty elections twentytwo years ago.

What about other explanations? Some scholars suggest that the existence of cross-cutting cleavages can dampen ethnic polarization in the electoral system. ${ }^{161}$ They hypothesize that while overlapping cleavages can reinforce conflict, the existence of cross-cutting cleavages diminishes the importance of any one identity dimension. Both Senegal and Benin have some cross-cutting ties. In Senegal, an ethnic Wolof

\footnotetext{
${ }^{159}$ Touba is the holy place of the Mouridiyya, whereas Tivaouane is the holy place of the Tijaniyya. The most important pilgrimage for the Mourides is the Magal, whereas for Tijanis it is the Gammu.

${ }^{160}$ See Banégas 2003, 8-9.

${ }^{161}$ E.g., Dahl 1956; Lipset and Rokkan 1967; Dunning and Harrison 2010.
} 
could be a member of several different Sufi brotherhoods. Likewise, in Benin, most ethnic groups are diverse with respect to religion. For example, an ethnic Fon could be a member of different Christian denominations or practice indigenous religion. Vodoun, the main indigenous practice, crosses ethnic and geographic lines.

The existence of overlapping cleavages in general does not help us account for the variation in the extent of ethnic politics in our cases, but what about specific cross-cutting ties? For example, Dunning and Harrison, using a highly innovative experiment in Mali, show that cross-cutting ties based on an informal institution of joking kinship, or cousinage, can counterbalance ethnic ties. ${ }^{162}$ Cousinage also exists in Senegal, but its importance in Senegalese politics should not be overstated. I witnessed how joking relations are routinely invoked in everyday interactions in Senegal, but direct evidence that they feature prominently in national electoral campaigns is lacking. For example, whereas appeals to religious leaders or other intermediaries, or ethnic appeals in Benin, are chronicled extensively in the press, references to politicians invoking cousinage ties with voters are strikingly absent.

It may be the case that even when nominal joking kinship exists, whether it is used may depend on local cultural and political entrepreneurs. ${ }^{163}$ Galvan argues that the use of cousinage ties is itself endogenous to existing alliances. For example, he suggests that in some instances interethnic Serer-Wolof joking kinships have not emerged on any meaningful scale because of the ongoing political and economic competition between the Serer and the Wolof. ${ }^{164}$ In other words, the nominal ties afforded by joking kinship create an opportunity to counterbalance the salience of ethnicity, but this opportunity is not always exploited. The examples of ethnic tensions in Casamance, the site of an ethnic rebellion, and ethnic voting in the latest (and the country's first) free multiparty elections in Guinea, both parts of West Africa where

${ }^{162}$ Dunning and Harrison 2010, 22.

${ }^{163}$ Galvan 2006 suggests that joking kinship is not invoked uniformly and that "generalizations about its [joking kinship's] causal impact across circumstances, time and space is nearly impossible" (p. 824).

${ }^{164}$ Galvan 2006, 818-19. As Galvan further explains, [among the Serer] "redeployment of interfamilial joking kinship to include Wolofs seems to hinge on the degree of personalism, of face-to-face contact linking a Wolof Faye and the Serer Diouf." Only when "such a relationship exists between people who live in the same community, are part of the same occupational or patronage network, or otherwise have cause to come into fairly regular face-to-face contact with one another" actors have actively used joking kinships between the Serer and the Wolof (Galvan 2006, 819). On the contrary, cousinage ties seem to be ignored when they are inopportune. As Galvan 2006 argues: "[I]t is certainly the case that when individuals who belong to distinct, rival clientelistic networks enter into conflict, clientelistic loyalties often neutralize the cooperative effects of joking kinships that may bind the same individuals" (p. 823). 
the institution of cousinage is present, show that this informal institution is not by itself a sufficient condition for interethnic cooperation. ${ }^{165}$

\section{Generalizability}

Does the argument apply beyond the cases examined here? Is Senegal an anomalous and singular case? There is evidence to suggest that it is not. Mali, for example, is also a very diverse state without pronounced ethnic voting blocs ${ }^{166}$ and where local leaders were politically influential. ${ }^{167}$ Several different scholars of Malian politics document how the first successful mass parties, such as the Parti Soudanais Progressiste (PSP), built their electoral support across ethnic lines through rural chiefs and marabouts. ${ }^{168}$ Since Mozambique, another country with low levels of ethnic politics, started regular political competition in the 1990s, scholars have noted politicians' use of intermediaries. ${ }^{169}$ Botswana also presents a similar pattern of electoral mobilization, albeit within the bounds of a more homogenous society. Historically, it had very strong traditional leadership, which was preserved under the British Protectorate. ${ }^{170}$ Successive governments since independence have relied on traditional leadership to harness electoral support, as well as to gain backing for various government reforms and programs. ${ }^{171}$ Political elites continuously rely on these local structures to encourage political participation. ${ }^{172}$ The prominence of traditional Malian or Tswana leadership is not the norm across Africa. It is in stark contrast to Kenya, for example, one of the most oft cited examples of ethnic politics. Most segments of Kenyan society, including the leading Kikuyu and Luo groups, have long manifested weak social hierarchies. ${ }^{173}$

Limited availability of comparable cross-national data prevents us from testing the theory on a large number of cases. We do, however, have data on the role of traditional leaders from the Afrobarometer

\footnotetext{
${ }^{165}$ On cousinage between Diola and other ethnic groups and ethnic rebellion in Casamance, see Galvan 2006; de Jong 2005; and Villalón 1995, 54-56. And for the example of cousinage in Guinea, see Dunning and Harrison 2010, 37. For the ethnic character of Guinean elections, see BBC 2012; Jeune Afrique 2010. Incidentally, Guinea is also the country that witnessed under Sekou Touré the most extensive postcolonial destruction of traditional authority.

${ }^{166}$ Wing 2008; Dunning and Harrison 2010; Baudais and Sborgi 2008.

167 Morgenthau 1964; Imperato 1989; Diop 1971; Hopkins 1972.

${ }^{168}$ Morgenthau 1964, 256-57; Hodgkin and Morgenthau 1964, 223; Snyder 1965, 59.

${ }^{169}$ West and Kloeck-Jenson 1999.

${ }^{170}$ Holm 1993; Molutsi 1998.

${ }^{171}$ Somolekae and Lekorwe 1998; Holm 1988; Onoma 2006.

${ }^{172}$ Holm 1993, 107.

${ }^{173}$ Murdoch 1967.
} 
survey and the level of ethnic politics for thirteen countries (including Senegal and Benin). ${ }^{174}$ It is certainly not a sufficient number for a proper quantitative test of the theory, but it allows us to probe the theory's generalizability. Relying on question 49i from round 4 (2008) of the Afrobarometer survey, which asks respondents how much they trust traditional leaders, I use the percentage of interviewees in a given country stating that they trust traditional leaders "a lot" as a proxy for that country's strength of hierarchical ties. I combine this with the measure of the association between ethnic identity and vote choice, introduced in Figure 1. These data show that the higher the trust in traditional leaders, the lower the level of ethnic voting. The correlation between these two variables is -0.43 . Although this cannot be treated as a definitive test, this relationship provides some suggestive evidence, as it is in the direction predicted by the theory. ${ }^{175}$

We can also point to subnational variation consistent with the theory. For example, in Ghana the group with the highest strength of hierarchical ties seems to have less ethnic politics than other parts of the country. The Northern Dagomba show much higher levels of trust in traditional leaders than the two main ethnic groups, the Akan and Ewe, located in the South: 70 percent of Dagomba say they trust traditional leaders a lot, compared with 37 percent and 41 percent, respectively, for the other groups. At the same time, while the Akan and Ewe are each associated with a political party (the New Patriotic Party and the National Democratic Congress, respectively), the Dagomba seem much more fluid in their electoral support and there is no "Dagomba" party or presidential candidate. ${ }^{176}$

There is also evidence that chiefs' allegiance in many settings is driven by their interests rather than their identity. As Van Kessel and Oomen argue in the case of South Africa, "chiefs often align themselves, whether wholeheartedly or for tactical reasons, with the powers that seem to offer the best chances of safeguarding their positions." 177 The same can be said about the Ghanaian intermediaries. During the early postindependence years, the $\mathrm{Ya}-\mathrm{Na}$ of Dagbon, the most prized

${ }^{174}$ These countries are Botswana, Senegal, Mozambique, Mali, Tanzania, Ghana, Madagascar, Nigeria, Uganda, Malawi, Namibia, Kenya, and Benin.

${ }^{175}$ The same relationship holds if we use another proxy for the strength of local leaders. I employed another question from the same Afrobarometer survey, this time asking respondents how much influence do traditional leaders have in governing their community (question 65). I used the percentage of interviewees that say "a great deal" as a proxy. The correlation between the role of leaders and the level of ethnic politics was -0.398 .

${ }^{176}$ Michelitch 2010 provides a good description of the Ghanaian ethnic electoral allegiances (esp. $3,8-9)$.

177 Van Kessel and Oomen 1997, 562. 
intermediary among the Dagomba, wanted to support the most likely winner. Although he initially sided with the NPP, as Nkrumah's CPP grew in strength, the Ya-Na switched his allegiance to the CPP. ${ }^{178}$ Elsewhere in Ghana, the Brong chiefs also decided to back Nkrumah for strategic reasons, because he promised them that he would take the Brong area away from Asante and turn it into a separate region. ${ }^{179} \mathrm{Af}-$ ter the chiefs supported Nkrumah, he kept his promise and created a new region, the Brong Ahafo. ${ }^{180}$ Another aspect of some Ghanaian chiefs' behavior also indicates that their allegiance is often strategic, rather than based on ethnic solidarity. In many chiefly families (just as in Senegalese maraboutic families) there were splits, with some members of the family supporting one candidate and others throwing their weight behind someone else. ${ }^{181}$

While the theory should apply to many settings with high levels of clientelist politics, there may be some additional boundary conditions worth considering. There may be limits to the fluidity of intermediaries' behavior and their willingness to support candidates across the board. For example, a rise in the salience of programmatic platforms could make certain alliances unpalatable to voters. Greater levels of party organization may also institutionalize local leaders within a given party, inhibiting their ability to switch loyalties.

\section{Conclusion}

This article has made the case for why social structure, with variable strength of local leaders, is an important factor in electoral politics, shaping both modes of voter mobilization and electoral outcomes. Rather than merely looking at the demographic data, politicians craft their strategies in response to the social environment in which voters live. Local leaders with strong ties to the population present politicians with an alternative to mobilizing voters based on ethnic ties between politicians and voters. An appreciation for how historical legacies condition the power of local leaders allows us to understand why their role in electoral politics is not uniform. As I have shown, Senegalese local elites have much more social clout than their counterparts in many other African states, such as Benin. Such leaders could thus act as credible intermediaries between politicians and voters, enabling politicians

\footnotetext{
${ }^{178}$ Staniland $1975,146$.

${ }^{179}$ Rathbone 2000, 78.

${ }^{180}$ Rathbone 2000, 82.

${ }^{181}$ Rathbone 2000, 79.
} 
to reach voters outside their own ethnic group and to create ethnically and religiously diverse electoral bases.

The findings presented in this article have important theoretical ramifications. The role of electoral intermediaries is important for several reasons. First, it contributes to a more complete understanding of the repertoire of voter mobilization in clientelist, nonprogrammatic settings. Membership in the same ethnic group is clearly not the only basis for clientelist electoral support in Africa, even if it is the one most frequently invoked. More importantly, mobilizing via intermediaries is not just another means to the same outcome. Intermediaries deserve our attention because they are not merely another layer in voter mobilization. Rather, they can have a transformative effect on electoral patterns. Intermediaries change electoral dynamics because unlike individual voters they are in a better position to forge ties with non-coethnic politicians. They have the capacity to produce surprisingly nonethnic voting patterns in highly ethnic societies. Highlighting the role of electoral intermediaries also helps us to disentangle clientelism and ethnicity and to resolve the tension between the literature on ethnic politics in Africa, which assumes that nominal ethnic ties are suitable for creating clientelist networks and many studies of clientelism, which highlight personal connections as the bedrock of clientelist networks. The article makes the case that when intermediaries serve as gatekeepers for access to resources, clientelist networks may not correspond with ethnic solidarities.

This article also complements recent work on local provision of resources and voter mobilization in other parts of the world, notably in India. ${ }^{182}$ Like Krishna's work, it makes the case that in an environment where many voters cannot access state resources, intermediation by local leaders is highly desirable to voters, and that those leaders who help people at the local level become attractive to political actors. While Krishna focuses on the effect of intermediation for villagers' access to various services, this article advances a new question, looking at the transformative effect of intermediation on electoral patterns and political actors' bases of support. Importantly, politicians' reliance on local leaders' ties of dependence with voters reflects a strategy of governing and not just of winning votes. Politicians do not need to connect with voters only on the eve of an election: incumbents, in particular, often rely on intermediaries to drum up support for unpopular government policies, dissipate discontent, or quell challenges or mass protests.

${ }^{182}$ Krishna 2011; Thachil 2011. 
Finally, the mode of clientelist mobilization, whether through direct ethnic appeals or via intermediaries, raises questions beyond the issues of ethnic inclusion, representation, and the composition of parties' electoral bases. For example, what impact do these different modes of clientelism have on redistribution? Do voters have better access to resources when they are mobilized via intermediaries, or are intermediaries the main beneficiaries of this system to the exclusion of voters? Does the intermediary system raise the total amount of money spent during political campaigns? Perhaps less money is spent on clientelism in affinity voting systems, but is there evidence that politicians spend the "unused" resources in a worthwhile manner, for example, on infrastructure or other goods? These questions point to the rich research agenda that emerges once the role of intermediaries and social structure is taken into account. Future research into the redistributive consequences of different types of mobilization is particularly warranted.

\section{REFERENCES}

Afrobarometer Briefing Paper 17. 2005. "Démocratie au Bénin: le point de vue de la population béninoise à partir de l'Enquête Afrobaromètre 2005."

Ajulu, Rok. 2002. "Politicised Ethnicity, Competitive Politics and Conflict in Kenya: A Historical Perspective." African Studies 61, no. 2: 251-68.

Banégas, Richard. 2003. La démocratie à pas de caméléon: transition et imaginaires politiques au Bénin [Democracy at Chameleon's Pace : Transition and Political Imaginary in Benin]. Paris, France: Karthala.

Bates, Robert. 1974. "Ethnic Competition and Modernization in Contemporary Africa." Comparative Political Studies 6: 457-84.

Battle, Martin, and Jennifer Seely. 2007. "It's All Relative: Competing Models of Vote Choice in Benin." Afrobarometer Working Paper 78.

Baudais, Virginie, and Enrico Sborgi. 2008. "The Presidential and Parliamentary Elections in Mali, April and July 2007." Electoral Studies 27, no. 4: 769-73.

BBC. 2012. Country Profiles: Guinea. At http://www.bbc.co.uk/news/world-africa -13442053, accessed March 15, 2012.

Beck, Linda. 1997. "Senegal's 'Patrimonial Democrats': Incremental Reform and the Obstacles to the Consolidation of Democracy." Canadian Journal of African Studies 31, no. 1: 1-31.

- 2001. "Reining in the Marabouts? Democratization and Local Governance in Senegal." African Affairs 100, no. 401: 601-21.

- 2008. Brokering Democracy in Africa: The Rise of Clientelist Democracy in Senegal. New York, N.Y.: Palgrave Macmillan.

Behrman, Lucy. 1970. Muslim Brotherhoods and Politics in Senegal. Cambridge, Mass.: Harvard University Press.

Bierschenk, Thomas. 2006. "The Local Appropriation of Democracy: An Analysis of the Municipal Elections in Parakou, Republic of Benin, 2002-3.” Journal of Modern African Studies 44, no. 4: 543-71. 
Boone, Catherine. 2003. Political Topographies of the African State: Territorial Authority and Institutional Choice. New York, N.Y.: Cambridge University Press.

Brusco, Valeria, Marcelo Nazareno, and Susan Stokes. 2007. "Poverty, Risk and Clientelism." Paper presented at the annual meeting of the American Political Science Association, Chicago, August 30-September 2.

Chandra, Kanchan. 2004. Why Ethnic Parties Succeed: Patronage and Ethnic Head Counts in India. New York, N.Y.: Cambridge University Press.

- 2006. "What Is Ethnicity and Does It Matter?" Annual Review of Political Science 9: 397-424.

Chazan, Naomi. 1982. "Ethnicity and Politics in Ghana." Political Science Quarterly 97, no. 3: 461-85.

Cheeseman, Nicholas, and Robert Ford. 2007. "Ethnicity as a Political Cleavage." Afrobarometer Working Paper 83.

Coulon, Christian. 1981. Le Marabout et le Prince: Islam et Pouvoir au Sénégal [The Marabout and the Prince: Islam and Power in Senegal]. Paris, France: Editions A. Pedone.

Cruise O’Brien, Donal. 1971. The Mourides of Senegal. Oxford, UK: Clarendon Press.

-1975. Saints and Politicians: Essays in the Organization of a Senegalese Peasant Society. New York, N.Y.: Cambridge University Press.

Dahl, Robert. 1956. A Preface to Democratic Theory. Chicago, Ill.: University of Chicago Press.

Decalo, Samuel. 1970. "Full Circle in Dahomey." African Studies Review 13, no. 3: 445-57.

- 1973. "Regionalism, Politics, and the Military in Dahomey." Journal of Developing Areas 7, no. 3: 449-78.

de Jong, Ferdinand. 2005. "A Joking Nation: Conflict Resolution in Senegal." Canadian Journal of African Studies 39, no. 2: 389-413.

Diallo, Boucar Aliou. 2007. "Touba - Wade chez le khalife general des mourides," Le Quotidien. March 3-4, 7.

Diop, Abdoulaye-Bara. 1981. La société Wolof: Les systèmes d'inégalité et de domination. [The Wolof Society: Systems of Inequality and Domination]. Paris, France: Karthala.

Diop, Alioune Badara. 2002. "Logiques sociales et démocratie électorale au Sénégal. Essai de reconstruction et d'interprétation d'une trajectoire de crise: l'exemple de Fouta Toro (1983-2001). "Ph.D. diss., Insitut d'Etudes Politiques de Bordeaux, Université Montesquieu-Bordeaux IV.

Diop, Georges Nesta. 2006. “Un government de mission . . électorale.” Walfadjri. November 24, 3.

Diop, Majhemout. 1971. Histoire de classes sociales dans l'Afrique de l'ouest (I): le Mali [History of Social Classes in West Africa: Mali]. Paris, France: François Maspero.

Diop, Momar-Coumba, Mamadou Diouf, and A. Diaw. 2000. "Le Baobab a été déracine: L'alternance au Sénégal.” Politique Africaine 78: 157-79.

Diouf, Makhtar. 1994. Sénégal: Les ethnies et la nation [Senegal: Ethnic Groups and the Nation]. Paris, France: L'harmattan.

Dowd, Robert, and Michael Driessen. 2008. "Ethnically Dominated Party Systems and the Quality of Democracy: Evidence from Sub-Saharan Africa." Afrobarometer Working Paper 92. 
Dresang, Dennis. 1974. "Ethnic Politics, Representative Bureaucracy and Development Administration: The Zambian Case." American Political Science Review 68, no. 4: 1605-17.

Dunning, Thad, and Lauren Harrison. 2010. "Cross-Cutting Cleavages and Ethnic Voting: An Experimental Study of Cousinage in Mali." American Political Science Review 104, no. 1: 21-39.

Faye, Ousseynou. 1994. "L'instrumentalisation de l'histoire et de l'ethnicité dans le discours séparatiste en Basse Casamance (Sénégal).” Afrika Spektrum 29, no. 1: 65-77.

Ferree, Karen. 2004. “The Microfoundations of Ethnic Voting: Evidence from South Africa.” Afrobarometer Working Paper 40.

Foltz, William. 1969. "Social Structure and Political Behavior of Senegalese Elites.” Behavior Science Notes 4: 145-63.

Franck, Raphaël, and Ilia Rainer. 2012. "Does the Leader's Ethnicity Matter? Ethnic Favoritism, Education, and Health in Sub-Saharan Africa." American Political Science Review 106, no. 2: 294-325.

Galvan, Dennis. 2001. "Political Turnover and Social Change in Senegal." Journal of Democracy 12, no. 3: 51-62.

- 2004. The State Must Be Our Master of Fire: How Peasants Craft Culturally Sustainable Development in Senegal. Berkeley and Los Angeles, Calif.: University of California Press.

- 2006. "Joking Kinship as a Syncretic Institution." Cahiers d'études africaines 4, no. 184: 809-834.

Glélé, Maurice. 1969. Naissance d'un état noir: L'évolution politique et constitutionnelle du Dabomey, de la colonisation a nos jours [Birth of a Black State: Political and Constitutional Evolution of Dahomey, from Colonization to the Present]. Paris, France: Librairie Générale de Droit et de Jurisprudence.

Hodgkin, Thomas, and Ruth Schachter Morgenthau. 1964. "Mali.” In James Coleman and Carl Rosberg, eds., Political Parties and National Integration in Tropical Africa. Berkeley and Los Angeles, Calif.: University of California Press.

Holm, John. 1988. "Botswana: A Paternalistic Democracy.” In Larry Diamond, Juan Linz, and Seymour Lipset, eds., Democracy in Developing Countries: Africa. Boulder, Colo.: Lynne Rienner Publishers.

- 1993. "Political Culture and Democracy: A Study of Mass Participation in Botswana." In Stephen Stedman, ed., Botswana: The Political Economy of Democratic Development. Boulder, Colo.: Lynn Rienner Publishers.

Hopkins, Nicholas. 1972. Popular Government in an African Town. Chicago, Ill., and London, UK: University of Chicago Press.

Horowitz, Donald. 1985. Ethnic Groups in Conflict. Berkeley, Calif.: University of California Press.

Imperato. Pascal. 1989. Mali: A Search for Direction. Boulder, Colo.: Westview Press. Jeune Afrique. 2010. "Cellou Dalein Diallo rend Alpha Condé responsable des violences ethniques." November 21.

Kasara. Kimuli. 2007. "Tax Me If You Can: Ethnic Geography, Democracy, and the Taxation of Agriculture in Africa." American Political Science Review 101, no. 1: 159-72.

Kaspin, Deborah. 1995. "The Politics of Ethnicity in Malawi's Democratic Transition." Journal of Modern African Studies 33, no. 4: 595-620. 
Klein, Martin. 1968. "The Evolution of the Chefferie in Senegal.” In Arnold Rivkin, ed., Nations by Design: Institution Building in Africa. Garden City, N.Y.: Anchor Books.

Kramon, Eric, and Daniel Posner. 2011. "Who Benefits from Distributive Politics? How the Outcome One Studies Affects the Answer One Gets." Massachusetts Institute of Technology, Political Science Department, Working Paper no. 2011-9.

. 2012. "Ethnic Favoritism in Primary Education in Kenya." Manuscript.

Krishna, Anirudh. 2011. "Gaining Access to Public Services and the Democratic State in India: Institutions in the Middle." Studies in Comparative International Development 46, no. 1: 98-117.

Lambert, Michael. 1998. "Violence and the War of Words: Ethnicity v. Nationalism in Casamance." Africa 68, no. 4: 585-602.

Le Matinal. 2006. January 26.

Lemarchand, René. 1972. "Political Clientelism and Ethnicity in Tropical Africa: Competing Solidarities in Nation-Building." American Political Science Review 66, no. 1: 68-90.

Lemarchand, René, and Keith Legg. 1972. "Political Clientelism and Development: A Preliminary Analysis.” Comparative Politics 4, no. 2: 149-78.

Lipset, Seymour, and Stein Rokkan. 1967. Party Systems and Voter Alignments: Cross-National Perspectives. New York, N.Y.: Free Press.

Logan, Carolyn. 2008. "Traditional Leaders in Modern Africa: Can Democracy and the Chief Co-Exist?" Afrobarometer Working Paper 93.

Lombard, Jacques. 1965. Structures de type "féodal" en Afrique Noire: Etudes des dynamismes internes et des relations sociales chez les Bariba du Dahomey [Feudal-type Structures in Black Africa: Studies of Internal Dynamics and Social Relations among the Bariba of Dahomey]. Paris, France: Mouton \& Co.

Magaloni, Beatriz. 2006. Voting for Autocracy: Hegemonic Party Survival and Its Demise in Mexico. New York, N.Y.: Cambridge University Press.

Mahoney, James, and Dietrich Rueschemeyer. 2003. "Comparative Historical Analysis: Achievements and Agendas." In James Mahoney and Dietrich Rueschemeyer, eds., Comparative Historical Analysis in the Social Sciences. Cambridge, UK: Cambridge University Press: 3-38.

Mayrargue, Cédric. 2006. "Yayi Boni, un president inattendu?" Politique Africaine 102: $155-72$.

McLaughlin, Fiona. 1995. "Haalpulaar Identity as a Response to Wolofization." African Languages and Cultures 8, no. 2: 153-68.

Michelitch, Kristin. 2010. "Do Elections Manipulate Patterns of Inter-ethnic or Inter-partisan Discrimination? A Field Experiment on Price Bargaining in Africa." Paper prepared for the 2010 University of Florida Frontiers in African Politics Workshop, January 27.

Molutsi, Patrick. 1998. "Elections and Electoral Experience in Botswana." In Wayne Edge and Mogopodi Lekorwe, eds., Botswana: Politics and Society. Pretoria, South Africa: J. L. van Schaik Publishers.

Morgenthau, Ruth. 1964. Political Parties in French-Speaking West Africa. Oxford, UK: Clarendon Press.

Murdoch, George. 1967. Ethnographic Atlas. Pittsburgh, Pa.: University of Pittsburgh Press. 
Ndao, El Hadj Ibrahima. 2003. Sénégal, histoire des conquêtes démocratiques [Senegal: History of Democratic Conquests]. Dakar, Senegal: Les Nouvelles Editions Africaines du Sénégal.

Ndegwa, Stephen. 1997. "Citizenship and Ethnicity: An Examination of Two Transition Moments in Kenyan Politics.” American Political Science Revierw 91, no. 3: 599-616.

Onoma, Ato. 2006. "Securing Property Rights: Politics on the Land Frontier in Postcolonial Africa.” Ph.D. diss., Northwestern University.

Padró i Miquel, Gerard. 2007. "The Control of Politicians in Divided Societies: The Politics of Fear." Review of Economic Studies 74: 1259-1274.

Patterson, Amy. 2002. "The Impact of Senegal's Decentralization on Women in Local Governance." Canadian Journal of African Studies 36, no. 3: 490-529.

Pélissier, Paul. 1966. Les Paysans du Sénégal: Les Civilisations Agraires du Cayor à la Casamance [The Peasants of Senegal: Agrarian Civilizations from Cayor to Casamance]. Saint-Yrieix, France : Imprimerie Fabrègue.

Posner, Daniel. 2003. "The Colonial Origins of Ethnic Cleavages: The Case of Linguistic Divisions in Zambia." Comparative Politics 35, no. 2: 127-46.

- 2005. Institutions and Ethnic Politics in Africa. New York, N.Y.: Cambridge University Press.

Powell, John. 1970. "Peasant Society and Clientelist Politics." American Political Science Review 64, no. 2: 411-25.

Rathbone, Richard. 2000. Nkrumah and the Chiefs: The Politics of Chieftaincy in Ghana 1951-60. Athens, Ohio: Ohio University Press.

Ronen, Dov. 1975. Dahomey: Between Tradition and Modernity. Ithaca, N.Y., and London, UK: Cornell University Press.

Schaffer, Frederic. 1998. Democracy in Translation. Ithaca, N.Y.: Cornell University Press.

Schaffer, Frederic, and Andreas Schedler. 2007. "What Is Vote Buying?" In Frederic Schaffer, ed., Elections for Sale: the Causes and Consequences of Vote Buying. Boulder, Colo.: Lynne Rienner Publishers.

Scott, James. 1972. "Patron-Client Politics and Political Change in Southeast Asia." American Political Science Review 66, no. 1: 91-113.

Seely, Jennifer. 2007. “The Presidential Election in Benin, March 2006.” Electoral Studies 26, no. 1: 196-231.

Smith, Etienne. 2006. “La nation 'par le côté': Le récit des cousinages au Sénégal.” Cabiers d'études africaines 4, no. 184: 907-65.

Snyder, Frank. 1965. One-Party Government in Mali: Transition toward Control. New Haven, Conn., and London, UK: Yale University Press.

Somolekae, Gloria, and Mogopodi Lekorwe. 1998. "The Chieftaincy System and Politics in Botswana, 1966-95." In Wayne Edge and Mogopodi Lekorwe, eds., Botswana: Politics and Society. Pretoria, South Africa: J. L. van Schaik Publishers.

Staniland, Martin. 1973. "The Three-Party System in Dahomey: I, 1946-56." Journal of African History 14, no. 2: 291-312.

Stokes, Susan. 2007a. "Pork, by Any Other Name: Building a Conceptual Scheme of Distributive Politics.” Manuscript, Yale University.

—. 2007b. "Political Clientelism." In Carles Boix and Susan Stokes, eds., Handbook of Comparative Politics. Oxford, UK: Oxford University Press: 604-27.

Tamari, Tal. 1991. "The Development of Caste Systems in West Africa." Journal of African History 32, no. 2: 221-50. 
Thachil, Tariq. 2011. "Embedded Mobilization: Nonstate Service Provision as Electoral Strategy in India." World Politics 63, no. 3 (July): 434-69.

Thompson, Virginia. 1963. "Dahomey." In Gwendolen Carter, ed., Five African States: Responses to Diversity. Ithaca, N.Y.: Cornell University Press: 161-262. van de Walle, Nicholas. 2003. "Presidentialism and Clientelism in Africa's Emerging Party Systems.” Journal of Modern African Studies 41, no. 2: 297-321

- 2007. "Meet the New Boss, Same as the Old Boss? The Evolution of Political Clientelism in Africa." In Herbert Kitschelt and Steven Wilkinson, eds., Patrons, Clients and Policies. Cambridge, UK: Cambridge University Press.

Van Kessel, Ineke, and Barbara Oomen. 1997. "One Chief, One Vote: The Revival of Traditional Authorities in Post-Apartheid South Africa." African Affairs 96, no. 385: 561-85.

Varshney, Ashutosh. 2002. Ethnic Conflict and Civic Life: Hindus and Muslims in India. New Haven, Conn.: Yale University Press.

Vicente, Pedro, and Leonard Wantchekon. 2009. "Clientelism and Vote Buying: Lessons from Field Experiments in African Elections." Oxford Review of Economic Policy 25, no. 2: 292-305.

Villalón, Leonardo. 1994. "Democratizing a (Quasi) Democracy: The Senegalese Elections of 1993." African Affairs 93, no. 371: 163-93.

- 1995. Islamic Society and State Power in Senegal. New York, N.Y.: Cambridge University Press.

Wantchekon, Leonard. 2003. "Clientelism and Voting Behavior: Evidence from a Field Experiment in Benin.” World Politics 55, no. 3 (April): 399-422.

West, Harry, and Scott Kloeck-Jenson. 1999. "Betwixt and Between: 'Traditional Authority' and Democratic Decentralization in Post-War Mozambique." African Affairs 98, no. 393: 455-84.

Wilkinson, Steven. 2004. Votes and Violence: Electoral Competition and Ethnic Riots in India. New York, N.Y.: Cambridge University Press.

Wing, Susanna. 2008. Constructing Democracy in Transitioning Societies of Africa: Constitutionalism and Deliberation in Mali. New York, N.Y.: Palgrave Macmillan.

Wrong, Michela. 2009. It's Our Turn to Eat: The Story of a Kenyan Whistleblower. New York, N.Y.: HarperColllins Publishers.

Young, Crawford, and Babacar Kante. 1991. "Governance, Democracy, and the 1988 Senegalese Elections." In Goran Hyden and Michael Bratton, eds., Governance and Politics in Africa. Boulder, Colo.: Lynne Rienner Publishers.

Zuccarelli, François. 1988. La vie politique sénégalaise (1940-1988) [Senegalese Political Life: 1940-1988]. Paris, France: CHEAM. 